\title{
Financial Stability of Islamic Finance
}

\author{
Ilyes Abidi (Corresponding author) \\ University of Tunis El Manar, Tunisia \\ E-mail: abidi.elyes@hotmail.fr \\ Mariem Nsaibi \\ University of Hail, Saudi Arabia
}

\begin{abstract}
Boutheina Regaieg
Faculty of Law, Economics and Management of Jendouba University of Jendouba, Tunisia
\end{abstract}

Received: December 17, 2019 Accepted: January 11, 2020 Published: March 10, 2020

doi:10.5296/ijafr.v10i1.16060

URL: https://doi.org/10.5296/ijafr.v10i1.16060

\begin{abstract}
The aim of this paper is to study the stability of the Islamic financial system. To do this, we are interested in the scoring method and the volatility of stock market indices.

The first empirical study includes all the components of the financial system, in particular, banks, insurance companies, leasing, factoring and investments companies.

The results of this study suggest that, Islamic finance saw a loss of $0.014 \%$ of its stability score, in 2007, against $0.43 \%$ and $1.675 \%$ for conventional finance, respectively in 2007 and 2008. In contrast, during the period of the Arab revolutions only Islamic finance depreciated.

In order to refine our research, we used the autoregressive conditional heteroscedasticit models to study the volatility of the DJ index and the DJIM index. The empirical results reveal that, the DJIM index is less volatile than the DJ index of emerging countries, Europe, Asia and the United States. However, the DJ Global Index is less volatile than the DJIM index, which seems paradoxical compared to previous results. From then on, we studied the volatility of the two indices before, during and after the crisis. The empirical results reveal that, the DJIM index is much more stable than the DJ index during the crisis (2007-2009). On
\end{abstract}


the other hand, before and after the crisis (2002-2006 and 2010-2015), the DJ Global index is more stable but the difference is insignificant.

Keywords: Stability, Islamic finance, Conventional finance, DJ indices and DJIM indices

\section{Introduction}

The Islamic financial model is a participatory model based on microfinance. It is based on the real economy and characterized by its prudential system. Despite its small share in the global financial market, Islamic finance has been one of the most dynamic sectors in recent decades and has gained new momentum in the wake of the financial crisis (Mosab I. Tabash and Raj S. Dhankar, 2015). During the crisis period, financial instability has taken root in the conventional system while Islamic finance is showing some health.

Indeed, the literature does not lead to a consensus on the stability of Islamic finance and therefore the sense of this impact remains mixed. It is in this context that we need to shed new light, through an empirical study, by testing the financial stability of the two financial systems. In this regard, this paper comes to enrich the financial literature since it provides empirical evidence on the stability of Islamic finance via two methods namely the volatility of stock indexes and the scoring method.

Likewise, this paper focuses on a wide time interval (2002-2015) including the 2001 crisis, the 2007 crisis and the period of the Arab revolutions. In addition, this research paper is designed to contribute to an inconclusive debate on the importance of Islamic finance.

\section{Literature Review}

This section provides an analytical review of the works on the stability of the Islamic and conventional financial system. The results are mixed and these different findings bear witness to the complexity of this concept.

Trabelsi, L., and al. (2019) compared the performance of international Islamic, conventional and mixed (Islamo-conventional) portfolios. The methodology used in this paper is based on the Markov regime change model and the ratio difference test of Sharpe, Ledoit and Wolf (2008). The results show a difference in performance between conventional, Islamic and mixed portfolios, but it is not statistically significant. In the same spinning mill, Bahloul, S., and al. (2017) examined the comparative performance of the diversification of Islamic and conventional portfolios over the period 2002-2014. In this work, Bahloul, S., and al. (2017) have shown that Islamic market indices can provide good coverage, providing investors with additional investment alternatives. Over the same period, Abu-Alkheil, A., and al. (2017) have shown that conventional indices dominate during the pre-crisis and the crisis periods, which offers diversification opportunities to global investors who hold both types of indices in the same portfolio. Using the stochastic dominance test, based on the bootstrap of Linton, Maasoumi and Whang (2005), Abu-Alkheil, A., and al. (2017) showed that conventional indices dominate their Islamic counterparts during the pre-crisis and the crisis periods. In the post-crisis period, by cons, there is no indication of dominance of one over the other type of indices. 


\section{MInstitute Mach $^{m}$}

International Journal of Accounting and Financial Reporting ISSN 2162-3082 2020, Vol. 10, No. 1

Miniaoui. H and al. (2015) examined the performance of Islamic and conventional indices of GCC countries and tested whether Islamic indices are less risky than conventional indices. The results of this investigation showed that the financial crisis has a negative impact on the average yields of the Bahraini index and has amplified the volatility of the indices of the United Arab Emirates, Kuwait and Bahrain. On the other hand, the crisis does not have a significant impact on the Islamic index and this throughout the study period 2006-2012. Given the political and geographical effects, Miniaoui, H., and al. (2015) demonstrated that the GCC country indexes admit increased volatility in 2006 following the loss of the Saudi stock market by $50 \%$ of its value. Thus, this loss is caused by bank panic of national and regional investors. In 2009, however, the United Arab Emirates, Kuwait and Bahrain indices reacted to the Dubai debt crisis, which created a high volatility in the indices of cooperation.

In summary, this research has shown that the DJIM index is less risky than the conventional DJ Global World index.

Like Grubel's (1968) research, Nekhili, R., and Muhammad, N. (2010) examined correlations between different markets in GCC countries. They used six market indexes from six GCC markets: UAE, Bahrain, Kuwait, Qatar, Saudi Arabia and Oman. The main conclusion of this review is that GCC markets are interdependent and do not provide any benefit to the international diversification of an investment portfolio. Despite the stock market interdependence and the homogeneity of GCC's markets, the results show high volatility differences between stock markets. These differences arise from the position taken by investors regarding the purchase or sale of shares. On the other hand, a strong persistence of volatility has been observed. This amounts to the fact that short selling is prohibited in these markets, hence the excessive sales of shares to liquidate the funds held.

Since Saudi Arabia and the UAE hold more than half of the market capitalization of the GCC market, $44 \%$ for Saudi Arabia and 21\% for the UAE, they are likely to have the most impact in the GCC market. To confirm or reject this hypothesis, Nekhili, R., and Muhammad, N. (2010) studied the conditional volatility of the GCC country market indices. The daily closing prices for the period January 6, 2003 to January 1, 2009 were used. The use of the conditional VAR allowed to conclude a strong relationship between the volatility of the Saudi index and those of Kuwait, United Arab Emirates, Qatar, Oman and Bahrain. This finding can be explained by the uncertainty of the yields of Saudi firms. The empirical results of this work suggest that:

- In bearish periods, Saudi Arabia negatively affects the future volatility of the Abu Dhabi market.

- The Abu Dhabi market is influenced by past innovations in the Qatar market and the Omani index is negatively impacted by Bahraini and Qatari indexes.

- In bullish periods, the Saudi market positively affects all GCC markets with the exception of the Bahrain market.

In their paper titled "Political uncertainty and stock market volatility in the Middle East and North African (MENA) countries", Frankie Chau, Rataporn Deesomsak and Jun Wang (2014) 


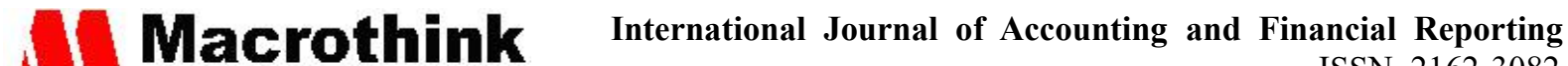 ISSN 2162-3082 2020, Vol. 10, No. 1}

investigated the impact of political uncertainty in the period of the Arab Spring on the volatility of the main stock markets in the MENA region. Because Islamic series contain some oil and gas industry indicators, Frankie Chau, Rataporn Deesomsak, Jun Wang (2014), hypothesize that the impact of the Arab Spring on Islamic clues is higher than conventional indexes. Then and using event analysis, Frankie Chau, Rataporn Deesomsak and Jun Wang (2014) found that stock prices react to political changes and collapse in troubled times. These results are comparable to those of Lobo (1999) who examined the American market during the 1998 election dilettante of the political scandal that took place. Similarly, Jackson (2008) and Chesneyet and al. (2011) have worked on terrorist attacks in many Western countries and confirm that the majority of these events have had a negative effect on the financial markets. This empirical validation was done using the GARCH method (because it allows to verify and control the conditional covariance of the returns of the stock market indices of the MENA countries) and the three international benchmarks namely, Arab index, Developed index and World index. Roughly, the results of this research work indicate that the Arab Spring conflicts and political uncertainty have increased the volatility of the MENA stock market indices (Bahrain, Kuwait, Oman, Egypt, Jordan and Lebanon) and especially those Islamic. This uncertainty was fueled by the lack of confidence of international investors in the region, resulting in a panic in the stock markets of the MENA countries.

Charles, A., Darné, O., and Pop, A. (2011) tried to verify whether Islamic indexes are more or less affected by unexpected changes in volatility regimes than conventional indexes. The results show that the Islamic and conventional indexes have been affected by the same degree of variance and admit the same trends (bearish or bullish). On the other hand, Islamic market indexes have higher average returns than conventional market indices, but they are also more volatile. According to Charles, A., Darné, O., and Pop, A. (2011), this volatility gap may be innate of the size factor. To answer this question, a study of the volatility of Canadian Islamic and conventional indexes took place. This empirical exercise resulted in the volatility of the Canadian Islamic Index being higher than that of the conventional index. To refine these results, Charles, A., Darné, O., and Pop, A. (2011) repeated Brown-Forsythe's tests to inspect the equality of variances across several size-defined subindices. The results of this test indicate that the size bias does not affect the equality of variances tests. However, the Shariaa-compliant large-cap portfolio is more volatile than large-cap companies included in conventional indexes. This amounts to saying that the Islamic index experienced abnormal volatility during the Asian crisis of 1997, the Russian crisis of 1998, the financial crisis of 2007 as well as the unexpected increase in interest rates, consumer price indices, commodity prices, unemployment rates and even terrorist attacks.

Beyond religious barriers, Islamic finance requires financial criteria for the valuation of investments. In order to ensure the compatibility of the selected securities, with their beliefs, investors in Islamic funds make use of a screening on the performance of the firms in question.

Hassan, A., Antoniou, A, and Paudyal, K. (2005) examined the impact of these restrictions on the performance of shariaa-compatible investments. They made a comparison between the performance characteristics of the Islamic index; index DJIM and Dow Jones-Americas index. 


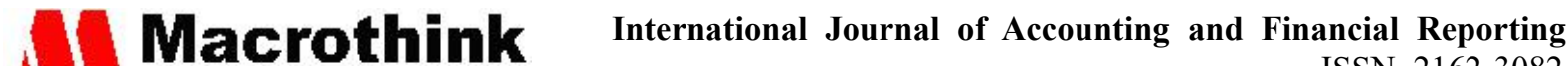 ISSN 2162-3082 2020, Vol. 10, No. 1}

In addition, they used the multifactorial model that controls the size, the market to book ratio, the momentary effect and the temporal variation of betas. The results show that the expected returns of the Islamic portfolios are higher than the expected returns of the conventional portfolios. Empirically speaking, Hassan, A., Antoniou, A, and Paudyal, K. (2005) used the CAPM model to estimate an additional return earned by a fund. The results of this work suggest that the DJIM index outperforms the benchmark, and the alpha of the DJIM index is larger than that of the CRSP benchmark $(0.8809, \mathrm{t}=2.80,0.8053, \mathrm{t}=2.72)$. The DJ Americas index, on the other hand, admits the same trend as that of the CRSP benchmark. In other words, the assumption that a diversified portfolio is able to perform better than a screened portfolio is rejected.

In the same vein, Hussein, K. A. (2005) attempted to test whether investors who acquire Shariaa-compatible shares admit returns different from those who invest in conventional shares. To answer this question, Hussein, K. A. (2005) used monthly returns of four indices namely: DJ Global index, FTSE Global index, FTSE Global Islamic index and DJIM index. The results of the CAPM model suggest that the Islamic index has greater volatility compared to the DJ Global index. On the other hand, it admits a better performance over the entire bullish period, namely, December 1993 to December 2000 and from September 2002 to December 2004. On the other hand, in the bearish period the DJIM index underperforms the DJ Global index. The results of the FTSE indices tend to be similar. The application of ethical screens does not therefore have a negative impact on the performance of the DJIM index and FTSE Global Islamic index. Both Islamic indexes are riskier than the DJGI, FTSE All-World and the benchmark « Morgan Stanley World Index All International ».

On the other hand, Al-Zoubi, A. H., and Maghyereh, I. A. (2007) likened depositors in Islamic banks to investors, or shareholders, who earn dividends when the bank makes a profit or loses some of their savings if the bank announces a loss. As a result, the system of sharing losses and profits can reduce the expected bankruptcy costs. In addition, Al-Zoubi, A. H., and Maghyereh, I. A. (2007) bode that the shareholders of the Islamic firms admit returns lower than those of the shareholders of the non-Islamic firms because of the financial leverage. In this work, Al-Zoubi, A. H., and Maghyereh, I. A. (2007) compared the DJIM index and the DJIS index over the period January 1996 - May 2005 to study the impact of financial screening. The results suggest that the two Islamic indices have unique risk characteristics and the ex-ante screening adopted by the DJIS has no impact on the expected gains. As a result, the DJIM index and the DJIS index have the same performance and belong to the same risk class. Referring to the works of Zoubi and Maghyereh (2007), Sukmana, R., and Kholid, M. (2010) studied the resilience of Islamic and conventional stock indices in Indonesia. They examined the performance and risk of the Islamic Index Jakarta Islamic Index and its similar Jakarta Composite Index. Using daily data from January 2001 to December 2009 and ARCH and GARCH methods, Sukmana, R., and Kholid, M. (2010), tried to verify if the financial crisis affects the volatility of individual stocks. The first observation of this study is that the volatility of the two indices is affected by the financial crisis. As well, this work suggests that JAKISL is less risky and less volatile than JCI, especially during the crisis.

By adopting the same method, Hussein, A. K. (2004) examined the hypothesis that there is a 
difference between the return on an investment in the FTSE Global Islamic Index shares and an investment in the shares of the FTSE All-World Index. In addition, a comparison of gross and risk-adjusted returns associated with investments in FTSE Global Islamic Index stocks and the FTSE All-World Index was made. The results show that the Islamic index outperformed the conventional index by 0.019 over the bull market (January 1996-March 2000) and underperformed during the downtrend (April 2000-July 2003). In summary, Hussein A.K (2004) suggests that additional costs incurred in tracking Islamic funds have no impact on expected returns.

Indeed, the debate on the financial stability of the two financial systems is not yet closed and the results are still mixed. The majority of works on this subject deals with samples consisting mainly of banks or homogeneous stock market indices, such as the work of Nekhili, R., and Muhammad, N. (2010). Similarly, some studies have methodological shortcomings, such as the work of Hassan, A., Antoniou, A., and Paudyal, K., (2005) who compared the performance of the DJIM index and the Dow Jones-Americas index. By the way, Miniaoui, H., and al. (2015) did not study the correlation between the different markets of the GCC countries.

Thus, the literature does not lead to a consensus on the stability of Islamic finance and therefore the sense of this impact remains mixed. It is in this context that we need to shed new light, through an empirical study, by testing the financial stability of the two financial systems. In this regard, this paper comes to enrich the financial literature since it provides empirical evidence on the stability of Islamic finance via two methods namely the volatility of stock indexes and the scoring method.

Likewise, this paper focuses on a wide time interval (2002-2015) including the 2001 crisis, the 2007 crisis and the period of the Arab revolutions. In addition, this research paper is designed to contribute to an inconclusive debate on the importance of Islamic finance.

\section{Methodology}

In order to study the stability of both financial systems, Islamic and conventional, and to make a comparison between them, we will use two methods namely the z-score and the volatility of the stock indices. The Z-score function can be defined as follows:

$$
\begin{aligned}
\mathrm{L}= & \alpha+\beta_{1} \mathrm{GIF}+\beta_{2} \mathrm{TIA}+\beta_{3} \mathrm{TP}+\beta_{4} \mathrm{CTI}+\beta_{5} \mathrm{GBF}+\beta_{6} \mathrm{ROE}+\beta_{7} \mathrm{IO}+\beta_{8} \mathrm{DIO} \\
& +\beta_{9} \mathrm{GA}+\beta_{10} \mathrm{WF}+\beta_{11} \mathrm{OFI}+\beta_{12} \mathrm{DJI}+\beta_{13} \mathrm{DJR}+\varepsilon_{\mathrm{it}}
\end{aligned}
$$

Then, in order to derive the respective stability levels of the two types of finance, we will use the exponential transformation of the logit model. This probabilistic relation can be expressed as follows:

$$
\mathrm{W}=\frac{1}{1+E x p}-\mathrm{L}
$$


Table 1. Definitions of the Z-Score variables of the two financial systems

\begin{tabular}{|c|c|c|c|}
\hline Variables & Definitions & Variables & Definitions \\
\hline GIF & $\begin{array}{l}\text { Gross insurance funds: } \\
\text { Total funds of insurance } \\
\text { companies }\end{array}$ & $\mathrm{DIO}$ & $\begin{array}{l}\text { Domestic Insurance Obligation }=\text { total } \\
\text { sum of domestic obligations }\end{array}$ \\
\hline TIA & $\begin{array}{l}\text { Total insurance asset: Sum } \\
\text { of the assets of insurance } \\
\text { companies. }\end{array}$ & GA & $\begin{array}{l}\text { Global asset }=\text { Total sum of assets of } \\
\text { institutions other than banks and } \\
\text { insurance companies. }\end{array}$ \\
\hline $\mathrm{TP}$ & $\begin{array}{l}\text { Total premium: total } \\
\text { insurance premiums }\end{array}$ & WF & $\begin{array}{l}\text { Worldwide funds }=\text { Total sum of funds } \\
\text { of institutions other than banks and } \\
\text { insurance companies. }\end{array}$ \\
\hline CTI & $\begin{array}{l}\text { Cost to Income Bank ratio } \\
=\text { Total cost } / \text { Net income }\end{array}$ & OFI & Other Financial Intermediaries \\
\hline GBF & $\begin{array}{l}\text { Global Banking Funds = } \\
\text { total funds of banks }\end{array}$ & DJI & Dj index \\
\hline ROE & Banking return on equity & DJR & World Index Total Return \\
\hline IO & $\begin{array}{l}\text { International Obligation }= \\
\text { total sum of international } \\
\text { obligations }\end{array}$ & & \\
\hline
\end{tabular}

Although the term volatility refers to the notion of risk, it is going to be used in this work as a study of financial stability. So ideally, the least stable system is the most volatile. To do this, we will study the volatility of the Dow Jones Global Index and DJIM World Index indices and their subdivisions over the period 2002-2015. The dataset includes the daily closing prices of the conventional and Islamic stock indexes presented below.

\begin{tabular}{llll}
\hline- & Dow Jones Global Index & - & DJIM World Index \\
\hline- & DJ Asia Pacific Index & - & DJIM Asia Pacific Index \\
\hline- & DJ Emerging Markets Index & - & DJIM Emerging Markets Index \\
\hline- & DJ Europe Index & - & DJIM Europe Index \\
\hline- & DJ U.S. Index & - & DJIM U.S. Index \\
\hline
\end{tabular}




\section{Mll Macrothink}

International Journal of Accounting and Financial Reporting

ISSN 2162-3082

2020, Vol. 10, No. 1

However, the Dow Jones Islamic Market Index was created in 1999 and is the second Islamic index, after Socially Aware Muslim Index created in 1998, made available to investors who want to invest in accordance with Shariaa. The DJIM index filters courses on two times. The first screening is done in accordance with shariaa by eliminating firms that invest in alcohol, weapons, pornography, tobacco and pork.

The second screening is done on the basis of the ratios and it admits three levels:

- Exclusion of companies whose total debt exceeds 33\% of market capitalization or total assets.

- Exclusion of companies whose available cash exceeds 33\% of their market capitalization or total assets.

- Exclusion of companies whose receivables exceed $45 \%$ of total assets.

The fundamental difference between an Islamic index and another conventional is that the former excludes some sectors deemed "unethical" and crowds out some companies that earn a significant income from the interest or exert excessive leverage (Frankie Chau, Rataporn Deesomsak \& Jun Wang, 2014).

However, we will be interested in the conditional volatility expressed by the models of the ARCH class. These processes were initiated by Engle (1982) who proposed an ARCH (q) specification where the square of errors follows an autoregressive process of order $\mathrm{q}$.

$$
\varepsilon_{\mathrm{t}}=\sigma_{\mathrm{t}} * \mathrm{Z}_{\mathrm{t}}
$$

Where $Z_{t}$ represents the stochastic component which is a white noise and follows the reduced normal centered law and $\sigma \mathrm{t}$ is the standard deviation such that:

$$
\begin{aligned}
\sigma^{2} & =\alpha_{0}+\alpha_{1} \varepsilon_{\mathrm{t}-1}^{2}+\ldots \ldots+\alpha_{\mathrm{q}} \varepsilon_{\mathrm{t}-\mathrm{q}}^{2} \\
& =\alpha_{0}+\sum_{i=1}^{q} \alpha_{\mathrm{i}} \varepsilon_{\mathrm{t}-\mathrm{i}}^{2}=\alpha_{0}+\alpha(\mathrm{L}) \varepsilon_{\mathrm{t}}^{2}
\end{aligned}
$$

Knowing that $\alpha(\mathrm{L})$ is the delay polynomial, and $\alpha_{0}$ and $\alpha_{\mathrm{i}}$ are positive $\forall \mathrm{i}$.

In fact, the ARCH model is an innovation of the Box-Jenkins ARMA model, which neglects the information contained in the residual factor of the series (constant variance) and which was initially schematized as follows:

$$
\mathrm{X}_{\mathrm{t}}=\varepsilon_{\mathrm{t}}+\sum_{i=1}^{p} \varphi_{\mathrm{i}} \mathrm{X}_{\mathrm{t}-1}+\sum_{i=1}^{q} \Theta_{\mathrm{i}} \varepsilon_{\mathrm{t}-1}
$$

Where $\varphi_{\mathrm{i}}$ and $\Theta_{\mathrm{i}}$ are constant and $\varepsilon_{\mathrm{t}}$ is a process-independent error term.

Initiated by Tim Bollerslev (1986), the generalized form of the ARCH model represented the variance $\sigma^{2}$ as the aggregation between the autoregressive term and the moving average of the residue squares. The GARCH model can be written as follows:

$$
\varepsilon_{\mathrm{t}}=\sigma_{\mathrm{t}} * \mathrm{Z}_{\mathrm{t}}
$$




\section{MInstitute ${ }^{\text {Macrothink }}$}

International Journal of Accounting and Financial Reporting ISSN 2162-3082 2020, Vol. 10, No. 1

With $\sigma_{\mathrm{t}}^{2}=\omega+\alpha_{1} \varepsilon_{\mathrm{t}-1}^{2}+\ldots \ldots+\alpha_{\mathrm{q}} \varepsilon_{\mathrm{t}-\mathrm{q}}^{2}+\beta_{1} \sigma_{\mathrm{t}-1}^{2}+\ldots .+\beta_{\mathrm{p}} \sigma_{\mathrm{t}-\mathrm{p}}^{2}$

$$
=\omega+\sum_{i=1}^{q} \alpha_{\mathrm{i}} \varepsilon_{\mathrm{t}-1}^{2}+\sum_{i=1}^{p} \beta_{\mathrm{i}} \sigma_{\mathrm{t}-1}^{2}
$$

Where $\omega$ and $\alpha_{\mathrm{t}}>0$ and $\beta_{\mathrm{j}} \geq 0, \forall \mathrm{i}=1 \ldots \mathrm{p}$ and $\mathrm{j}=1 \ldots \mathrm{q}$

As for the model E-GARCH it is written in the following form:

$$
\varepsilon_{\mathrm{t}}=\sigma_{\mathrm{t}} * Z_{\mathrm{t}}
$$

With $\operatorname{Ln}\left(\sigma^{2} \mathrm{t}\right)=\omega+\sum_{k=1}^{q} \beta_{\mathrm{k}} \mathrm{g}\left(\mathrm{Z}_{\mathrm{t}-\mathrm{k}}\right)+\sum_{k=1}^{p} \alpha_{\mathrm{k}} \operatorname{Ln}\left(\sigma_{\mathrm{t}-\mathrm{k}}^{2}\right)$

such as $g\left(Z_{t}\right)=\theta Z_{t}+\lambda\left(\left|Z_{t}\right|-E\left(\left|Z_{t}\right|\right)\right)$

Where $\sigma_{t}^{2}$ is the conditional variance.

This model was introduced by Nelson (1991), he suggests that the variance depends on the size and the sign of the delayed residuals. Although it does not impose any restrictions on the end of the parameter sign, this model is a limitation of the GARCH model. This is innate of the logarithmic form in which the conditional variance has been represented.

Like the GARCH and E-GARCH model, the GJR-GARCH model is meant to limit the persistence of volatility in time series. It therefore makes it possible to exponentially reduce the autocorrelation of errors. This model was advanced by Glosten, Jagannathan and Rukle (1993) and it is written as follows:

$$
\sigma_{\mathrm{t}}^{2}=\mathrm{K}+\delta \sigma_{\mathrm{t}-1}^{2}+\alpha \varepsilon_{\mathrm{t}-1}^{2}+\Phi \varepsilon_{\mathrm{t}-1}^{2} \mathrm{I}_{\mathrm{t}-1}
$$

Where $\mathrm{I}_{\mathrm{t}-1}=0$ if $\varepsilon_{\mathrm{t}-1} \geq 0$ and $\mathrm{I}_{\mathrm{t}-1}=1$ si $\varepsilon_{\mathrm{t}-1}<0$

\section{Results and Interpretations}

Table 2. Descriptive statistics of Islamic finance

\begin{tabular}{llllll}
\hline Variable & Obs & Mean & Std. Dev. & Min & Max \\
\hline r1 & 14 & 6.9005 & 5.300262 & .829 & 17.114 \\
\hline r2 & 14 & 1.084071 & .4368747 & .451 & 1.741 \\
\hline r3 & 14 & 1.163071 & .8257433 & .115 & 2.54 \\
\hline r4 & 14 & 47.27143 & 5.40917 & 40.2 & 58 \\
\hline r5 & 14 & .7812857 & .615751 & .067 & 1.819 \\
\hline r6 & 14 & 27.16571 & 6.382318 & 15.862 & 38.068 \\
\hline r7 & 14 & .0152325 & .0186524 & .00113 & .059565 \\
\hline r8 & 14 & .0499177 & .0439079 & .000241 & .117331 \\
\hline
\end{tabular}




\begin{tabular}{llllll}
\hline $\mathrm{r} 9$ & 14 & .9699286 & .7408345 & .15 & 2.48 \\
\hline $\mathrm{r} 10$ & 14 & 50.24786 & 19.58571 & 16.42 & 81.7 \\
\hline $\mathrm{r} 11$ & 14 & .0097725 & .0088676 & .0002056 & .02559 \\
\hline $\mathrm{r} 12$ & 14 & 2065.726 & 492.4607 & 1195.49 & 2800.01 \\
\hline $\mathrm{r} 13$ & 14 & 2592.704 & 852.4866 & 1413.49 & 4051.23 \\
\hline
\end{tabular}

Table 3. Descriptive statistics on conventional finance

\begin{tabular}{|c|c|c|c|c|c|}
\hline Variable & Obs & Mean & Std. Dev. & Min & $\operatorname{Max}$ \\
\hline $\mathrm{r} 1$ & 14 & 20.45727 & 5.445679 & 10.32215 & 27.40359 \\
\hline $\mathrm{r} 2$ & 14 & 59.58564 & 14.16993 & 37.923 & 81.249 \\
\hline r3 & 14 & 40.08273 & 7.160578 & 26.26898 & 48.42968 \\
\hline $\mathrm{r} 4$ & 14 & 60.39214 & 3.880075 & 54.31 & 66.88 \\
\hline r5 & 14 & 96.61992 & 37.35497 & 39.13813 & 148.5813 \\
\hline r6 & 14 & 23.50143 & 3.714478 & 17.95 & 28.72 \\
\hline r7 & 14 & 19.00136 & 5.385772 & 8.758 & 26.775 \\
\hline r8 & 14 & 49.66771 & 13.66571 & 28.328 & 70.682 \\
\hline r9 & 14 & 1338.745 & 4894.453 & 15.113 & 18344 \\
\hline $\mathrm{r} 10$ & 14 & 208.2017 & 73.8116 & 91.82195 & 305.3477 \\
\hline r11 & 14 & 50.03294 & 18.10082 & 22.42661 & 75.23461 \\
\hline $\mathrm{r} 12$ & 14 & 245.6221 & 55.6615 & 140.54 & 320.86 \\
\hline r13 & 14 & 3702.81 & 1181.3 & 1785.86 & 5646.15 \\
\hline
\end{tabular}

Based on Tables 2 and 3 we note that the conventional insurance sector is significantly larger than the Islamic one. Conventional insurance has 34 times more premium than Islamic insurance. This seems totally logical because it admits a larger client and services portfolio than Islamic insurance. In addition, it admits 3 times more funds and 55 times more assets than takaful companies. In contrast, conventional banks are less profitable and less productive than Islamic banks. 
Table 4. Stability of Islamic finance and conventional finance (per year)

\begin{tabular}{|c|c|c|c|}
\hline Year & Islamic finance & \multicolumn{2}{|c|}{ Conventional Finance } \\
\hline 2002 & $97,5853 \%$ & \multicolumn{2}{|l|}{$88,3778 \%$} \\
\hline 2003 & $97,4201 \%$ & \multicolumn{2}{|l|}{$88,1537 \%$} \\
\hline 2004 & $97,3243 \%$ & \multicolumn{2}{|l|}{$88,7332 \%$} \\
\hline 2005 & $97,3900 \%$ & \multicolumn{2}{|l|}{$89,2225 \%$} \\
\hline 2006 & $97,4471 \%$ & \multicolumn{2}{|l|}{$89,6904 \%$} \\
\hline 2007 & $97,4336 \%$ & \multicolumn{2}{|l|}{$89,3086 \%$} \\
\hline 2008 & $97,4591 \%$ & \multicolumn{2}{|l|}{$87,8253 \%$} \\
\hline 2009 & $97,4821 \%$ & \multicolumn{2}{|l|}{$89,5373 \%$} \\
\hline 2010 & $97,5654 \%$ & \multicolumn{2}{|l|}{$89,9692 \%$} \\
\hline 2011 & $97,4442 \%$ & \multicolumn{2}{|l|}{$90,3798 \%$} \\
\hline 2012 & $97,3961 \%$ & \multicolumn{2}{|l|}{$90,4085 \%$} \\
\hline 2013 & $97,4267 \%$ & \multicolumn{2}{|l|}{$90,4284 \%$} \\
\hline 2014 & $97,4738 \%$ & \multicolumn{2}{|l|}{$90,5927 \%$} \\
\hline 2015 & $97,5428 \%$ & \multicolumn{2}{|l|}{$91,0942 \%$} \\
\hline Average & $97,4565 \%$ & \multicolumn{2}{|l|}{$89,5515 \%$} \\
\hline Wilcoxon test & $\begin{array}{l}\text { Ho: score FI = } \\
\text { score FC }\end{array}$ & $\mathbf{z}=3.296$ & $\begin{array}{l}\text { Prob }>|\mathbf{z}|= \\
0.0010\end{array}$ \\
\hline \multirow{3}{*}{ Student's test } & \multirow{3}{*}{ Ho: $\operatorname{mean}($ diff $)=0$} & $\begin{array}{l}\text { Ha: } \operatorname{mean}(\text { diff })< \\
0\end{array}$ & $\operatorname{Pr}(\mathrm{T}<\mathrm{t})=1.0000$ \\
\hline & & $\begin{array}{l}\text { Ha: } \\
\text { mean(diff) } !=0\end{array}$ & $\operatorname{Pr}(|\mathrm{T}|>|\mathrm{t}|)=0.0000$ \\
\hline & & $\begin{array}{l}\text { Ha: } \operatorname{mean}(\text { diff })> \\
0\end{array}$ & $\operatorname{Pr}(T>t)=0.0000$ \\
\hline
\end{tabular}

From Table 4, we note that Islamic finance is more stable than conventional finance. It admits an average stability score of $97.4565 \%$ against $89.5515 \%$ for conventional finance. In 2001 , the economic world experienced a collapse caused by terrorist acts in the USA. Although these acts were attributed to a Muslim extremist community, conventional finance was more degrading than Islamic finance. In fact, investments in Sharia-compatible funds rose from \$ 0.10142 trillion in 2000 to $\$ 0.16758$ in 2004 [E\&Y 2004-2014], and net profits rose from $\$ 0.1495$ to $\$ 0.329$ trillion. This stems from the fact that investors in Islamic funds are not ready to give up their profits which resulted in the increase of deposits from 0.1384 to 0.147 TD in 2004. 


\section{Mll Macrothink}

International Journal of Accounting and Financial Reporting ISSN 2162-3082 2020, Vol. 10, No. 1

In 2007 , Islamic finance saw a loss of $0.014 \%$ of its stability score against $0.43 \%$ and $1.675 \%$ for conventional finance, respectively in 2007 and 2008. By contrast, during the period of the Arab revolutions only Islamic finance depreciated. This depreciation resulted in a drop in the stability score of $0.17 \%$. The latter, increased from $97.565 \%$ in 2011 to $97.396 \%$ in 2012 . On the other hand, conventional finance has experienced a period of rivalry between 2010 and 2015, a period in which the global DJ index has risen from 253.9 to 307.9 dollars, that is to say $21.27 \%$ growth in 6 years only.

Thus and in accordance with Bourkhis and al. (2010) and Hasan and Dridi (2010), we can say that although Islamic finance is more sensitive to macro and micro changes, it presents a higher level of stability than conventional finance. However, in order to confirm these results, we used the study of time series. This method will allow us to study the dynamics of the volatility of Islamic and conventional stock market indices and to deduce which of the two indices is more stable.

Table 5. Descriptive statistics of conventional indices

\begin{tabular}{ccccccccccc}
\hline & \multicolumn{2}{c}{ DJ Asia Pacific Index } & \multicolumn{2}{c}{ DJ Emerging Markets } & \multicolumn{2}{c}{ DJ Europe Index } & \multicolumn{2}{c}{ DJ U.S. Index } & \multicolumn{2}{c}{ Dow Jones Global Index } \\
\cline { 2 - 12 } & PT & RI & PT & RI & PT & RI & PT & RI & PT & RI \\
\hline Mean & 121.9357 & 0.000155 & 229.1359 & 0.000260 & 264.1967 & $8.76 E-05$ & 333.9668 & 0.000185 & 240.1665 & 0.000147 \\
\hline Median & 128.4000 & 0.000541 & 253.8300 & 0.000790 & 262.1600 & 0.000327 & 314.2800 & 0.000645 & 242.0000 & 0.000499 \\
\hline Maximum & 172.4900 & 0.090085 & 355.8100 & 0.117624 & 407.8800 & 0.105123 & 537.3200 & 0.109116 & 341.6200 & 0.086635 \\
\hline Minimum & 61.16000 & -0.097360 & 73.77000 & -0.154588 & 128.2300 & -0.101296 & 165.3600 & -0.096336 & 124.9000 & -0.071600 \\
\hline Std. Dev. & 26.94386 & 0.011752 & 76.66658 & 0.012667 & 63.07511 & 0.014132 & 93.99105 & 0.012559 & 55.61500 & 0.010208 \\
\hline Skewness & -0.599972 & -0.519097 & -0.512963 & -1.321523 & -0.000622 & -0.054180 & 0.690118 & -0.269696 & -0.091494 & -0.368539 \\
\hline Kurtosis & 2.318856 & 10.19578 & 1.909475 & 23.65112 & 2.272260 & 9.788609 & 2.515215 & 11.84242 & 2.052872 & 11.65681 \\
\hline Jarque-Bera & 289.7773 & 8045.285 & 341.2156 & 65975.35 & 80.61055 & 7016.340 & 325.7365 & 11945.20 & 141.6353 & 11489.23 \\
\hline Probability & 0.000000 & 0.000000 & 0.000000 & 0.000000 & 0.000000 & 0.000000 & 0.000000 & 0.000000 & 0.0000000 & 0.000000 \\
\hline Sum & 445431.1 & 0.565391 & 837033.6 & 0.947958 & 965110.5 & 0.320141 & 1219981. & 0.675253 & 877328.0 & 0.5383322 \\
\hline Sum Sq. Dev. & 2651248. & 0.504378 & 21465597 & 0.585992 & 14529371 & 0.729302 & 32262926 & 0.576061 & 11295741 & 0.380544 \\
\hline Observations & 3653 & 3653 & 3653 & 3653 & 3653 & 3653 & 3653 & 3653 & 3653 & 3653 \\
\hline
\end{tabular}

Table 6. Descriptive statistics of Islamic indices

\begin{tabular}{ccccccccccc}
\hline & \multicolumn{2}{c}{$\begin{array}{c}\text { DIM Asia Pacific } \\
\text { Index }\end{array}$} & \multicolumn{2}{c}{$\begin{array}{c}\text { DIM Emerging } \\
\text { Markets Index }\end{array}$} & \multicolumn{2}{c}{ DJM Europe Index } & DIM U.S. Index & DIM World Index \\
\cline { 2 - 13 } & PT & RI & PT & RI & PT & RI & PT & RI & PT & RI \\
\hline Mean & 1245.660 & 0.000130 & 1765.306 & 0.000107 & 2509.854 & 0.000119 & 2321.445 & 0.000196 & 2032.144 & 0.000156 \\
\hline Median & 1318.470 & 0.000643 & 1926.720 & 0.000594 & 2552.760 & 0.000425 & 2147.490 & 0.000566 & 2033.720 & 0.000408 \\
\hline Maximum & 1695.880 & 0.096905 & 2678.870 & 0.107995 & 3539.030 & 0.114505 & 3858.020 & 0.117405 & 3035.320 & 0.097746 \\
\hline Minimum & 663.8300 & -0.098780 & 778.4200 & -0.120430 & 1246.240 & -0.099083 & 1205.730 & -0.096970 & 1073.260 & -0.081855 \\
\hline Std. Dev. & 266.5084 & 0.011885 & 478.4758 & 0.012521 & 595.9664 & 0.013906 & 712.0248 & 0.012119 & 502.1899 & 0.010358 \\
\hline Skewness & -0.526387 & -0.518894 & -0.425074 & -0.646949 & -0.213858 & 0.026436 & 0.750324 & -0.075938 & 0.150571 & -0.257326 \\
\hline Kurtosis & 2.056857 & 11.33468 & 1.906507 & 12.47234 & 1.958992 & 11.16612 & 2.462813 & 11.79248 & 2.124557 & 12.89590 \\
\hline Jarque-Bera & 304.0897 & 10737.36 & 292.0084 & 13911.74 & 192.7931 & 10150.53 & 386.6874 & 11770.39 & 130.4558 & 14945.89 \\
\hline Probability & 0.000000 & 0.000000 & 0.000000 & 0.000000 & 0.000000 & 0.000000 & 0.000000 & 0.000000 & 0.000000 & 0.000000 \\
\hline Sum & 4550396. & 0.476494 & 6448664 & 0.390754 & 9168495 & 0.435691 & 8480237 & 0.714829 & 7423422. & 0.568650 \\
\hline Sum Sq. Dev. & $2.59 \mathrm{E}+08$ & 0.515829 & $8.36 \mathrm{E}+08$ & 0.572508 & $1.30 \mathrm{E}+09$ & 0.706196 & $1.85 \mathrm{E}+09$ & 0.536335 & $9.21 \mathrm{E}+08$ & 0.391848 \\
\hline Observations & 3653 & 3653 & 3653 & 3653 & 3653 & 3653 & 3653 & 3653 & 3653 & 3653 \\
\hline
\end{tabular}




\section{$\Lambda$ Macrothink}

International Journal of Accounting and Financial Reporting

ISSN 2162-3082

2020, Vol. 10, No. 1

The results shown in Tables 5 and 6 that the DJIM index is better rated than the DJ index in Asia, Europe, US and emerging countries. Similarly, the DJIM index is more profitable than the DJ index in Europe and US. On the other hand, the DJ Asia index and the DJ emerging index outperform the DJIM Asia index and the DJIM emerging index.

In theory, skewness measures the asymmetry coefficient of a distribution around its mean while kurtosis measures the level of flattening of a distribution in relation to a normal distribution. The results of the Jarque-Bera test show that the indices do not follow the normal law, so we reject the null hypothesis of normality of the series because the skewness and the kurtosis are respectively different from 0 and 3. Indeed, the test of Jarque-Bera is given by the following relation:

$$
\text { Jarque-Bera }=\frac{N}{6}\left(\mathrm{~S}^{2}+\frac{(K-3)^{2}}{4}\right)
$$

Where S reflects asymmetry and K reflects flattening.

In continuity with the Jarque-Bera model, we studied the normality of the processes by means of the symmetry and flattening hypotheses defined by $Z_{1}$ and $Z_{2}$ such that:

$Z_{1}=\frac{|S|}{\sqrt{(6 / T)}}$ such that $H_{0}: Z_{1}$ follows the reduced normal centered law (T observation number).

$Z_{2}=\frac{|K-3|}{\sqrt{(24 / T)}}$ such that $Z_{2}$ follows the reduced normal centered law with $H_{0}$ : flattening close to normal (T observation number).

Based on $Z_{1}$ and $Z_{2}$ we can conclude that the series distribution is asymmetric and leptocurtic. However, since $Z_{1}$ and $Z_{2}$ are greater than the tabulated value 1.96 , we can reject the hypothesis of the Gaussian distribution of the series.

In addition, the descriptive statistics tables tell us that the series of returns do not follow the normal distribution. All in all, the skuwness coefficients are not zero and the kurtosis are not equal to 3 and the series of the returns have asymmetries on the left since the skuness is negative (except for DJIM Europe Index as it shows a positive skuness). Under the assumption of normality of the distribution, we notice that the series of returns follow the chi-square law with two degrees of freedom (at the threshold of 5\%).

The general finding of stock index studies is that the price series are non-stationary. Despite this usual conclusion, it seems necessary to validate this conquest. To do this, we used the $\mathrm{ADF}$ test in its 3 forms namely:

1. Model with constant and trend.

2. Model with constant and without trend.

3. Model without neither constant nor trend.

These models can be schematized as follows: 


$$
\begin{gathered}
\Delta \mathrm{Y}_{\mathrm{t}}=\alpha+\beta_{\mathrm{t}}+\varphi \mathrm{y}_{\mathrm{t}-1}+\sum_{t=1}^{P} \theta_{\mathrm{i}} \Delta y_{\mathrm{t}}-1+\varepsilon_{\mathrm{t}} \\
\Delta \mathrm{Y}_{\mathrm{t}}=\alpha+\varphi \mathrm{y}_{\mathrm{t}-1}+\sum_{t=1}^{P} \theta_{\mathrm{i}} \Delta y_{\mathrm{t}}-1+\varepsilon_{\mathrm{t}} \\
\Delta \mathrm{Y}_{\mathrm{t}}=\varphi \mathrm{y}_{\mathrm{t}-1}+\sum_{t=1}^{P} \theta_{\mathrm{i}} \Delta y_{\mathrm{t}}-1+\varepsilon_{\mathrm{t}}
\end{gathered}
$$

Applying the ADF test on stock index series, we concluded that all series have a level of calculated statistical t over the critical values at the $1 \%$ threshold, which means that the series are non-stationary at the level of $1 \%$.

In order to make these series stationary we proceed to the logarithmic difference which is none other than the process of yields. This relation can be written in the following form:

$$
\mathrm{R}_{\mathrm{t}}=\operatorname{Ln}\left(\mathrm{P}_{\mathrm{t}}\right)-\operatorname{Ln}\left(\mathrm{P}_{\mathrm{t}-1}\right)
$$

Where $\mathrm{P}_{\mathrm{t}}$ and $\mathrm{P}_{\mathrm{t}-1}$ are respectively the prices at the date $\mathrm{t}$ and $\mathrm{t}-1$.

In support of the $\mathrm{ADF}$ and $\mathrm{H}_{0}$ test, which states that the series of returns are stationary, we concluded that the series of returns are stationary at the $1 \%$ level.

Unlike previous work, we did not use the float method to specify ARMA model parameters.

\begin{tabular}{|c|c|c|c|c|}
\hline & $\begin{array}{lr}\text { Number } & \text { of } \\
\text { estimated } & \text { ARMA } \\
\text { models } & \end{array}$ & $\begin{array}{l}\text { Number of } \\
\text { non-converged } \\
\text { estimations }\end{array}$ & $\begin{array}{l}\text { Selected } \\
\text { ARMA } \\
\text { model }\end{array}$ & AIC value \\
\hline $\begin{array}{l}\text { DJ Asia } \\
\text { Pacific Index }\end{array}$ & 25 & 0 & $(4,4)(0,0)$ & -6.05405573303 \\
\hline $\begin{array}{l}\text { DJ Emerging } \\
\text { Markets Index }\end{array}$ & 25 & 0 & $(3,3)(0,0)$ & -5.93387180374 \\
\hline DJ Europe Index & 25 & 0 & $(1,3)(0,0)$ & -5.68647550662 \\
\hline DJ U.S. Index & 25 & 0 & $(3,3)(0,0)$ & -5.9294916161 \\
\hline $\begin{array}{l}\text { Dow Jones } \\
\text { Global Index }\end{array}$ & 25 & 0 & $(2,3)(0,0)$ & -6.35323268313 \\
\hline
\end{tabular}
Rather, we used the ARIMA Model Forecasting test on the yield series. The results of this test suggest that the time series are of the $\operatorname{ARMA}(p, q)$ type as presented in the following tables:

Table 27. Results of the ARMA model test of conventional indexes 
Table 28. Results of the ARMA model test of Islamic indexes

$\begin{array}{lrlrl}\text { Number } & \text { of } & \text { Number } & \text { of } & \text { Selected } \\ \text { estimated } & \text { ARMA } & \text { non-converged } & \text { ARMA } & \text { AIC value } \\ \text { models } & & \text { estimations } & \text { model } & \end{array}$

DJIM Asia

Pacific Index

0

$(4,4)(0,0)$

$-6.03164543984$

DJIM

Emerging

25

0

$(2,3)(0,0)$

$-5.95298580028$

Markets Index

DJIM Europe

Index

25

0

$(1,3)(0,0)$

$-5.71978275148$

DJIM

U.S.

Index

25

0

$(3,4)(0,0)$

$-6.00063302103$

DJIM World
Index

25

0

$(3,2)(0,0)$

$-6.31467119291$

Based on the stock index graphs, we notice that both types of indices had a bullish period until 2007. This increasing pace was resumed in 2009 and amortized in 2011 during political uprisings in Arab countries. We also notice that they have the same tendencies in times of crisis and out of crisis thing that coincides with the results of Charles, A., Darné, O., Pop, A. (2011) which states that:

- The Islamic and conventional indices have been affected by the same degree of variance and admit the same trends (bearish or bullish).

- Islamic market indexes have higher average returns than conventional market indices, but they are also volatile.

Based on the graphs of the series of returns, presented in Figure 2, we can notice that they are not homoscedastic. They are characterized by periods of strong disturbance and others of tranquility. We also visualize the existence of several volatility packages. This calls into question the assumption of constancy of so-called "Homoscedasticity" volatility.

In the same context, the models ARCH (Autoregressive Conditional Heteroskedasticity) and GARCH (Generalized ARCH) are widely used in the literature. In practice, they have been used to model unequal variances, or heteroscedastic, in financial time series and then study the existence of ARCH effect.

To this end, we used the regression model "Y" defined as follows: 


$$
\begin{gathered}
\mathrm{Y}=\mathrm{Xa}+\varepsilon \text { such as: } \varepsilon_{\mathrm{t}}=\mathrm{u}_{\mathrm{t}} * \mathrm{~h}_{\mathrm{t}} \text { and } \mathrm{u}_{\mathrm{t}} \sim \mathrm{N}(0,1) \\
\mathrm{h}_{\mathrm{t}}{ }^{2}=\alpha_{0}+\sum_{i=1}^{p} \alpha_{\mathrm{i}} \varepsilon_{\mathrm{t}-\mathrm{i}}{ }^{2}=\alpha_{0}+\alpha(\mathrm{B}) \varepsilon_{\mathrm{t}}{ }^{2}
\end{gathered}
$$

With $\alpha(\mathrm{B})=\alpha_{1} \mathrm{~B}+\alpha_{2} \mathrm{~B}^{2}+\alpha_{3} \mathrm{~B}^{3}+\ldots .+\alpha_{\mathrm{p}} \mathrm{B}^{\mathrm{p}}$

We suppose that: $H_{0}: \alpha_{1}=\alpha_{2}=\alpha_{3}=\alpha_{p}=0$

$\mathrm{H}_{1}: \alpha_{1} \neq 0 \forall_{\mathrm{i}}$

For there to be an ARCH effect, it is necessary that the hypothesis of equality of the coefficients is rejected if not $\sigma_{\mathrm{t}}^{2}=\alpha_{0}$. Empirically speaking, we use the following regression:

$$
\mathrm{e}_{\mathrm{t}}^{2}=\alpha_{0}+\sum_{i i=1}^{P p} \alpha_{\mathrm{i}} \mathrm{e}^{2} \mathrm{t}-\mathrm{i}
$$

As $e^{e}$ is the set of estimation residuals deduced from the ARMA model.

The application of Engle's ARCH test (1982) confirms the existence of an Arch effect. In addition, the graphs of the series of the yields show us that the series are highly volatile. We observe volatility groupings around 2001, 2007 and 2011 that coincide with either a crisis or popular uprisings. This amounts to saying that the series of yields react well to a negative shock than to a positive shock, which can be an indicator of non-collinearity.

After taking into account the existence of an ARCH effect, it is necessary to determine the optimum number of lag that each chronological series can contain. The appropriate methodology, in this case, is the estimation of vector autoregression. The results of this estimate are summarized in the following tables:

\begin{tabular}{|c|c|c|c|c|c|c|c|c|}
\hline DJ Asia & $\begin{array}{l}\text { Akaike } \\
\text { AIC }\end{array}$ & $-6,0485$ & $-6,0478$ & $-6,0481$ & $-6,0475$ & $-6,0477$ & $-6,0482$ & $-6,0479$ \\
\hline Index & $\begin{array}{l}\text { Schwarz } \\
\text { SC }\end{array}$ & $-6,0451$ & $-6,0427$ & $-6,0413$ & $-6,0390$ & $-6,0375$ & $-6,0362$ & $-6,0343$ \\
\hline
\end{tabular}

Table 33. Results of ARCH LAGS test of conventional indexes

$$
[1 ; 1] \quad[1 ; 2] \quad[1 ; 3] \quad[1 ; 4] \quad[1 ; 5] \quad[1 ; 6] \quad[1 ; 7]
$$

$\begin{array}{lllllllll}\text { DJ } & \text { Akaike } & -5,9258 & -5,9308 & -5,9338 & -5,9334 & -5,9331 & -5,9339 & -5,9345 \\ \text { Emerging } & \text { AIC } & & & & & & & \\ \begin{array}{l}\text { Markets } \\ \text { Index }\end{array} & \begin{array}{l}\text { Schwarz } \\ \text { SC }\end{array} & -5,9224 & -5,9257 & -5,9270 & -5,9249 & -5,9229 & -5,9220 & -5,9209\end{array}$

$$
\begin{array}{lllllllll}
\text { DJ Europe } & \text { Akaike } & -5,6798 & -5,6799 & -5,6827 & -5,6838 & -5,6881 & -5,6874 & -5,6875 \\
\text { Index } & \text { AIC } & -5,60
\end{array}
$$


$\begin{array}{llllllll}\text { Schwarz } & -5,6764 & -5,6748 & -5,6759 & -5,6753 & -5,6779 & -5,6755 & -5,6739 \\ \text { SC } & -5,6\end{array}$

\begin{tabular}{|c|c|c|c|c|c|c|c|c|}
\hline DJ U,S & $\begin{array}{l}\text { Akaike } \\
\text { AIC }\end{array}$ & $-5,9217$ & $-5,9238$ & $-5,9232$ & $-5,9230$ & $-5,9244$ & $-5,9236$ & $-5,9237$ \\
\hline Index & $\begin{array}{l}\text { Schwarz } \\
\text { SC }\end{array}$ & $-5,9183$ & $-5,9187$ & $-5,9164$ & $-5,9145$ & $-5,9142$ & $-5,9117$ & $-5,9101$ \\
\hline Dow Jones & $\begin{array}{l}\text { Akaike } \\
\text { AIC }\end{array}$ & $-6,3488$ & $-6,3505$ & $-6,3498$ & $-6,3492$ & $-6,3512$ & $-6,3510$ & $-6,3504$ \\
\hline Index & $\begin{array}{l}\text { Schwarz } \\
\text { SC }\end{array}$ & $-6,3454$ & $-6,3454$ & $-6,3430$ & $-6,3407$ & $-6,3410$ & $-6,3391$ & $-6,3368$ \\
\hline
\end{tabular}

Table 34. Results of ARCH LAGS test of Islamic indexes

\begin{tabular}{|c|c|c|c|c|c|c|c|c|}
\hline & & {$[1 ; 1]$} & {$[1 ; 2]$} & {$[1 ; 3]$} & {$[1 ; 4]$} & {$[1 ; 5]$} & {$[1 ; 6]$} & {$[1 ; 7]$} \\
\hline \multirow{2}{*}{$\begin{array}{l}\text { DJIM Asia Pacific } \\
\text { Index }\end{array}$} & Akaike AIC & $-6,0265$ & $-6,0258$ & $-6,0275$ & $-6,0274$ & $-6,0279$ & $-6,0287$ & $-6,0291$ \\
\hline & Schwarz SC & $-6,0231$ & $-6,0207$ & $-6,0207$ & $-6,0189$ & $-6,0177$ & $-6,0167$ & $-6,0154$ \\
\hline \multirow{2}{*}{$\begin{array}{l}\text { DJM Emerging } \\
\text { Markets Index }\end{array}$} & Akaike AIC & $-5,9487$ & $-5,9480$ & $-5,9479$ & $-5,9490$ & $-5,9496$ & $-5,9515$ & $-5,9518$ \\
\hline & Schwarz SC & $-5,9453$ & $-5,9429$ & $-5,9411$ & $-5,9405$ & $-5,9394$ & $-5,9396$ & $-5,9382$ \\
\hline \multirow{2}{*}{$\begin{array}{l}\text { DJIM } \\
\text { Index }\end{array}$} & Akaike AIC & $-5,7133$ & $-5,7137$ & $-5,7174$ & $-5,7181$ & $-5,7205$ & $-5,7200$ & $-5,7200$ \\
\hline & Schwarz SC & $-5,7099$ & $-5,7086$ & $-5,7106$ & $-5,7096$ & $-5,7103$ & $-5,7081$ & $-5,7064$ \\
\hline \multirow{2}{*}{ DJIM U.S. Index } & Akaike AIC & $-5,9940$ & $-5,9978$ & $-5,9974$ & $-5,9973$ & $-5,9979$ & $-5,9972$ & $-5,9980$ \\
\hline & Schwarz SC & $-5,9906$ & $-5,9927$ & $-5,9906$ & $-5,9888$ & $-5,9877$ & $-5,9853$ & $-5,9844$ \\
\hline \multirow{2}{*}{$\begin{array}{l}\text { DJIM } \\
\text { Index }\end{array}$} & Akaike AIC & $-6,3095$ & $-6,3112$ & $-6,3109$ & $-6,3104$ & $-6,3126$ & $-6,3123$ & $-6,3115$ \\
\hline & Schwarz SC & $-6,3061$ & $-6,3061$ & $-6,3041$ & $-6,3019$ & $-6,3024$ & $-6,3004$ & $-6,2979$ \\
\hline
\end{tabular}

In order to select the number of lags optimums, we based ourselves on the criterion of AIC "Akaike Information Criterion" and that of SC "Schwarz". Based on these criteria, we noticed that the delays diverge for the DJ Emerging index, DJ index, US index and DJ Global 
index. In other words, the optimum lag to be retained according to the AIC criterion is not the same as that according to the criterion SC. Under the principle of parsimony that requires retaining the minimum minima, we chose the AIC criterion.

Then, we used the GARCH, E-GARCH and GJR-GARCH models to model the volatility of Islamic and conventional indices. To specify the most appropriate models for modeling the volatilities of both index types, we used the AIC and SC criteria and summarized the results in the following tables:

Table 35. Summary of ARCH, GARCH, EGARCH and GJR-GARCH tests of conventional indexes

\section{ARCH GARCH EGARCH GJR-GARCH}

\begin{tabular}{lccccc}
\hline & Akaike AIC & -6.119332 & -6.343361 & -6.360902 & -6.362791 \\
\cline { 2 - 6 } DJ Asia Pacific Index & Schwarz SC & -6.100635 & -6.322965 & -6.338806 & -6.340695 \\
\hline \multirow{2}{*}{$\begin{array}{l}\text { DJ Emerging Markets } \\
\text { Index }\end{array}$} & Akaike AIC & -6.335644 & -6.340756 & -6.385384 & -6.369784 \\
\cline { 2 - 6 } & Schwarz SC & -6.310154 & -6.323763 & -6.366692 & -6.351092 \\
\hline \multirow{3}{*}{\begin{tabular}{l} 
DJ Europe Index \\
\cline { 2 - 6 }
\end{tabular}} & Akaike AIC & -6.029701 & -6.089464 & -6.118237 & -6.117507 \\
\cline { 2 - 6 } & Schwarz SC & -6.011017 & -6.075876 & -6.102950 & -6.102220 \\
\hline \multirow{2}{*}{ DJ U.S. Index } & Akaike AIC & -6.368088 & -6.408568 & -6.444034 & -6.450561 \\
\cline { 2 - 6 } & Schwarz SC & -6.345997 & -6.391575 & -6.425341 & -6.431868 \\
\hline & Akaike AIC & -6.769984 & -6.824893 & -6.863133 & -6.855073 \\
\cline { 2 - 6 } & Schwarz SC & -6.749597 & -6.809603 & -6.846144 & -6.838083
\end{tabular}

Table 36. Summary of ARCH, GARCH, EGARCH and GJR-GARCH tests of Islamic indexes

\section{ARCH GARCH EGARCH GJR-GARCH}

\begin{tabular}{llllll}
\hline \multirow{2}{*}{$\begin{array}{l}\text { DJIM Asia Pacific } \\
\text { Index }\end{array}$} & Akaike AIC & -6.328276 & -6.349757 & -6.374450 & -6.371175 \\
\cline { 2 - 6 } & Schwarz SC & -6.299381 & -6.329360 & -6.352354 & -6.349079 \\
\hline \multirow{2}{*}{ DJIM Emerging } & Akaike AIC & -6.283135 & -6.308898 & -6.333120 & -6.330075 \\
\hline
\end{tabular}




\begin{tabular}{lccccc}
\hline Markets Index & Schwarz SC & -6.259350 & -6.293608 & -6.316131 & -6.313086 \\
\hline \multirow{2}{*}{ DJIM Europe Index } & Akaike AIC & -5.824985 & -6.116093 & -6.144674 & -6.140836 \\
\cline { 2 - 6 } & Schwarz SC & -5.813095 & -6.102504 & -6.129387 & -6.125549 \\
\hline \multirow{2}{*}{ DJIM U.S. Index } & Akaike AIC & -6.405550 & -6.420211 & -6.464045 & -6.462266 \\
\cline { 2 - 6 } & Schwarz SC & -6.378361 & -6.401519 & -6.443653 & -6.441874 \\
\hline \multirow{2}{*}{ DJIM World Index } & Akaike AIC & -6.723283 & -6.769815 & -6.812484 & -6.798280 \\
\cline { 2 - 6 } & Schwarz SC & -6.702891 & -6.754521 & -6.795491 & -6.781287 \\
\hline
\end{tabular}

Based on the results presented in Tables 35 and 36 we retained the following models:

Table 37. Models selected for Islamic and conventional indexes

\begin{tabular}{llll}
\hline Index & Model & Index & Model \\
\hline DJ Asia Pacific Index & GJR-GARCH & DJIM Asia Pacific Index & EGARCH \\
\hline DJ Emerging Markets Index & EGARCH & DJIM Emerging Markets Index & EGARCH \\
\hline DJ Europe Index & EGARCH & DJIM Europe Index & EGARCH \\
\hline DJ U.S. Index & GJR-GARCH & DJIM U.S. Index & EGARCH \\
\hline
\end{tabular}

In view of the figure 3, showing the respective volatilities of stock market indexes, we note that the DJIM index is more stable than the DJ index. In other words, the DJIM index is less volatile than the DJ index of Europe, Asia, US and emerging countries. In order to improve our results, we used Fisher's Equality Variables test to compare the volatility averages of the different indexes.

Table 38. Fisher test of equality of variances

\begin{tabular}{|c|c|c|c|c|c|}
\hline & & & Mean Abs. & Mean Abs. & Mean Tukey \\
\hline & & Std. Dev. & Mean Diff. & $\begin{array}{l}\text { Median } \\
\text { Diff. }\end{array}$ & Siegel Rank \\
\hline \multirow{2}{*}{ Asia Pacific Index } & $\mathrm{DJ}$ & 0.000198 & $9.21 \mathrm{E}-05$ & 7.77E-05 & 3720.997 \\
\hline & DJIM & 0.000167 & $8.56 \mathrm{E}-05$ & $7.53 \mathrm{E}-05$ & 3578.003 \\
\hline Emerging & $\mathrm{DJ}$ & 0.000302 & 0.000111 & $9.22 \mathrm{E}-05$ & 3670.418 \\
\hline
\end{tabular}




\begin{tabular}{llllll}
\hline Index & DJIM & 0.000193 & $9.66 \mathrm{E}-05$ & $8.48 \mathrm{E}-05$ & 3631.587 \\
\hline \multirow{2}{*}{ Europe Index } & DJ & 0.000235 & 0.000133 & 0.000117 & 3608.574 \\
\cline { 2 - 6 } & DJIM & 0.000235 & 0.000127 & 0.000111 & 3696.426 \\
\hline U.S. Index & DJ & 0.000277 & 0.000130 & 0.000105 & 3609.593 \\
\hline \multirow{2}{*}{ Global Index } & DJIM & 0.000178 & $9.72 \mathrm{E}-05$ & $8.36 \mathrm{E}-05$ & 3691.407 \\
\hline
\end{tabular}

Using the ANOVA method and the criteria of Bartlett, Levene and Brown-Forsythe, we concluded that regional Islamic indexes are more stable than conventional indices. Paradoxically, the DJIM index is more volatile than the DJ Global index between 2002 and 2015.

Although this coincides with that of CHARLES, A., DARNÉ, O., POP, A. (2011), we assume that this superiority of volatility is insignificant because of its ephemeral effect. By dividing the study period into 3 sub-periods namely 2002-2006, 2007-2009 and 2010-2015, we noticed that Islamic finance is much more stable than conventional finance in times of crisis whereas in times of out of crisis the advantage of conventional finance is insignificant as presented in the following tables.

Table 39. Summary of ARCH, GARCH, EGARCH and GJR-GARCH tests

\begin{tabular}{llllll}
\hline $2002-2006$ & ARCH & GARCH & EGARCH & GJR-GARCH \\
\hline \multirow{2}{*}{ DJ } & Akaike AIC & -6.903029 & -7.116306 & -7.136308 & -7.135486 \\
\cline { 2 - 6 } & Schwarz SC & -6.871291 & -7.080601 & -7.096562 & -7.095814 \\
\hline \multirow{2}{*}{ DJIM } & Akaike AIC & -6.740697 & -6.963495 & -6.996193 & -7.025648 \\
\cline { 2 - 6 } & Schwarz SC & -6.704992 & -6.923824 & -6.952473 & -6.982009 \\
\hline
\end{tabular}

Table 40. Summary of ARCH, GARCH, EGARCH and GJR-GARCH tests

\begin{tabular}{llllll}
\hline $2007-2009$ & ARCH & GARCH & EGARCH & GJR-GARCH \\
\hline \multirow{2}{*}{ DJ } & Akaike AIC & -5.784540 & -6.022531 & -6.034317 & -6.038330 \\
\cline { 2 - 6 } & Schwarz SC & -5.730995 & -5.968986 & -5.974822 & -5.978835 \\
\hline \multirow{2}{*}{ DJIM } & Akaike AIC & -5.823576 & -6.051457 & -6.071355 & -6.069773 \\
\cline { 2 - 6 } & Schwarz SC & -5.764081 & -5.991962 & -6.005911 & -6.004328 \\
\hline
\end{tabular}


Table 41. Summary of ARCH, GARCH, EGARCH and GJR-GARCH tests

\begin{tabular}{llllll}
\hline 2010-2015 & ARCH & GARCH & EGARCH & GJR-GARCH \\
\hline \multirow{2}{*}{ DJ } & Akaike AIC & -6.895800 & -17.05293 & -7.047877 & -7.027269 \\
\cline { 2 - 6 } & Schwarz SC & -6.865000 & -17.02555 & -7.017078 & -6.996469 \\
\hline \multirow{2}{*}{ DJIM } & Akaike AIC & -6.884273 & -6.972861 & -7.036456 & -7.015804 \\
\cline { 2 - 6 } & Schwarz SC & -6.853474 & -6.945484 & -7.005641 & -6.985005 \\
\hline
\end{tabular}

Table 42. Fisher test of equality of variances

\begin{tabular}{llllll}
\hline & & & Mean Abs. & Mean Abs. & Mean Tukey- \\
\cline { 2 - 6 } & Variable & Std. Dev. & Mean Diff. & Median Diff. & Siegel Rank \\
\hline \multirow{2}{*}{$2002-2006$} & DJ & $5.30 \mathrm{E}-05$ & $3.70 \mathrm{E}-05$ & $3.34 \mathrm{E}-05$ & 1240.556 \\
\cline { 2 - 6 } & DJIM & $6.25 \mathrm{E}-05$ & $4.17 \mathrm{E}-05$ & $3.67 \mathrm{E}-05$ & 1365.300 \\
\hline \multirow{2}{*}{$2007-2009$} & DJ & 0.000331 & 0.000193 & 0.000154 & 780.1620 \\
\cline { 2 - 6 } & DJIM & 0.000296 & 0.000171 & 0.000139 & 788.8380 \\
\hline & DJ & $3.07 \mathrm{E}-09$ & $1.94 \mathrm{E}-09$ & $1.68 \mathrm{E}-09$ & 1565.500 \\
\cline { 2 - 6 } & DJIM & $7.53 \mathrm{E}-05$ & $4.76 \mathrm{E}-05$ & $4.19 \mathrm{E}-05$ & 1564.500 \\
\hline
\end{tabular}

This finding suggests that Islamic indexes are less volatile in bearish trends and admit a similar behavior to conventional indices in bullish periods. This corroborates with the fact that Islamic finance admits an anticrisogenic protectionist aspect.

By and large, Islamic finance is more stable than conventional finance. This observation is consistent with that of z-score so the stability of Islamic finance is more than a fiction, it is a reality.

\section{Conclusion}

The purpose of this work is to study the stability of both financial systems, Islamic and conventional. It interested in the volatility of stock market indexes as well as the scoring method of Jakubík .P and Teplý .P (2007 and 2011).

The scoring method used in the first investigation focuses on macroeconomic data collected from Global Databank, IMF database, and the BIG FOUR annual reports. The empirical results of this method show that Islamic finance is more stable than conventional finance and that Islamic finance is more sensitive than conventional finance to macro and microeconomic changes. 
In order to refine our research, we studied the volatility of the DJ Global index and the DJIM index. Overall, we used the EGARCH model for the regional indexes of the DJIM index (Asia Pacific Index, Emerging Markets Index, Europe Index and U.S Index), the DJ Emerging Index and DJ Europe Index. On the other hand, the GJR-GARCH is the most suitable model for the DJ Asia Pacific Index and the DJ U.S Index.

The results of this second empirical investigation reveal that the DJIM index is less volatile than the DJ index of emerging countries, Europe, Asia and the United States. In contrast, the DJ Global Index is less volatile than the DJIM index, which seems paradoxical compared to previous results. From then on, we studied the volatility of the two indices in the times of crisis and out of crisis. The results of these tests indicate that the DJIM index is much more stable than the DJ index in the times of crisis (2007-2009). On the other hand, before and after the crisis (2002-2006 and 2010-2015) the DJ Global index is more stable but the difference is insignificant. This confirms our research hypotheses and allows us to say that Islamic finance is much more stable than conventional finance. In other words, a diversified portfolio is not able to achieve better levels of performance and stability than a portfolio tracked.

\section{References}

Abu-Alkheil, A., Khan, W. A., Parikh, B., \& Mohanty, S. K. (2017). Dynamic co-integration and portfolio diversification of Islamic and conventional indices: Global evidence. The Quarterly Review of Economics and Finance, 66(C), 212-224.

Aik, N.-C., \& Tan, K.-E. (2012). Excessive volatility in Asia stock market around general election (GE) period. Asian Journal of Empirical Research, 5(10), 160-166.

Ali Saaid, A. E. (2011). Islamic banking structures: implications for risk and financial stability. Islamic Economic Studies, 20(2), 50.

Al-Zoubi, A. H., \& Maghyereh, A. I. (2007, March). The relative risk performance of Islamic finance: a new guide to less risky investments. International Journal of Theoretical and Applied Finance, 10(02), 235-249.

Arshada, S., \& Raza Rizvi, S. A. (2013). Sanctuary in the Midst of Crisis? A Look into Shariah Indices using Multivariate Garch Dcc. Global Review of Islamic Economics and Business, 1(2), 150-163.

Bahloul, S., Mroua, M., \& Naifar, N. (2017). Further evidence on international Islamic and conventional portfolios diversification under regime switching. Applied Economics, 49(39), 3959-3978.

Berger, et. al. (1997). Managerial entrenchment and capital structure decisions. The Journal of Finance, 52, 1411-1438.

Bollerslev, T. (1986). Generalized autoregressive conditional heteroskedasticity. Journal of Econometrics, 31, 307-327.

Boumediene, A., \& Caby, J. (2009). The stability of Islamic banks during the subprime crisis. Charles, A., et. al. (2014). Stock Exchange Mergers and Market Efficiency. Working paper, EA 4272. 


\section{Macrothink}

International Journal of Accounting and Financial Reporting ISSN 2162-3082 2020, Vol. 10, No. 1

Chau, F., Deesomsak, R., \& Wang, J. (2014). Political uncertainty and stock market volatility in the Middle East and North African (MENA) countries. Journal of International Financial Markets, Institutions \& Money, 1-33.

Chesneyet, et. al. (2011). The impact of terrorism on financial markets: An empirical study. Journal of Banking \& Finance, 35, 253-267.

Chortareas, E. G., Girardone, C., \& Ventouri, A. (2011). Bank supervision, regulation, and efficiency: Evidence from the European Union. Journal of Financial Stability.

Elyes, A. (2014). Performance of the Islamic Market Indexes. The International Journal of Business \& Management, 2(8), 199.

Engle, R. F. (1982). Autoregressive Conditional Heteroscedasticity with Estimates of the Variance of United Kingdom Inflation. Econometrica, 50(4), 987-1007.

Fuentes, H., Grifell-Tatjè, E., \& Perelman, S. (2001). A Parametric Distance Function Approach for Malmquist Productivity Index Estimation. Journal of Productiviy Analysis, 15, 79-94.

Gamaginta, D., \& Rokhim, R. (2011, December 19-21). The stability comparison between Islamic banks and conventional banks: evidence in Indonesia. Paper presented at the proceedings of the 8th international conference on Islamic economics and finance, Doha, Qatar.

Glosten, L. R., Jagannathan, R., \& Rukle, D. E. (1993). On the Relation between the Expected Value and the Volatility of the Nominal Excess Return on Stocks. The Journal of Finance, XLVIII(5), 1779-1801.

Grubel, G. H. (1968, December). Internationally Diversified Portfolios. American Economic Review, LVIII, 1299-1314.

Hamoudi, H. A. (2007). Social Justice or Muslim Cant? Langdellianism and the Failures of Islamic Finance. Cornell International Law Journal, 4, 90-133.

Hart, O. D. (1983). The market mechanism as an incentive scheme. Bell Journal of Economics, 14, 366-382.

Hassan, A., Antoniou, A., \& Paudyal, K. (2005). Impact of ethical screening on investment performance: the case of the dow jones islamic index. Islamic Economic Studies, 12(2), 67-97.

Hassan, M. K. (2000). Market Efficiency, Time-Varying Volatility and Equity Returns in Bangladesh Stock Market. RG Paper (pp.1-25).

Hatem Hatef, A. A., et. al. (2013). Testing the Financial Stability of Banks in GCC Countries: Pre and Post Financial Crisis. International Journal of Business and Social Research (IJBSR), 3(4), 93-105.

Heremans, D. (2007). Corporate Governance Issues for Banks: A Financial Stability Perspective (pp.1-28). KUL, Center for Economic Studies.

Ibrahim, A. A. (2006). Convergence of Corporate Governance and Islamic Financial Services Industry: Toward Islamic Financial Services Securities Market (pp.1-21). The 


\section{Mll Macrothink}

International Journal of Accounting and Financial Reporting

ISSN 2162-3082 2020, Vol. 10, No. 1

Berkeley Electronic Press.

Jakubik, P., \& Teply, P. (2007). Scoring as an indicator of financial stability. CNB Financial Stability Report 2007 (pp. 76-85).

Jakubik, P., \& Teply, P. (2011). The JT index as an indicator of financial stability of corporate sector. Prague Economic Papers, 2, 157-176.

Lupu, I. (2015). The Indirect Relation between Corporate Governance and Financial Stability. Procedia Economics and Finance, 22, 538-543.

Mat Rahim, S. R., \& Zakaria, R. H. (2013). Comparison on stability between Islamic and conventional banks in Malaysia. Journal of Islamic Economics Banking and Finance, 9, 131-149.

Miniaoui, H., et. al. (2015). The Impact of Financial Crisis on Islamic and Conventional Indices of the GCC Countries. The Journal of Applied Business Research, 357-370.

Okumus, H. S., \& Artar, O. K. (2012). Islamic banks and financial stability in the GCC: An empirical analysis. Istanbul Ticaret Üniversitesi Sosyal Bilimler Dergisi, 11(21), 147-164.

Pejman, A., Philip, M., \& Tarazi, A. (2011). Risk and Stability in Islamic Banking. HAL, $1-54$.

Regaieg, B., \& Abidi, E. (2015). Islamic banks in the time of the credit subprime: a study of the X-efficiency by the SFA method. International Journal of Innovation and Applied Studies, $10(1), 45$.

Saint Pierre Eilleen, F. (1998). Estimating EGARCH-M models: Science or art?. The Quarterly Review of Economics and Finance, 38(2), 167-180.

Sakarya, B. (2016). Financial Stability of Islamic (Participation) Banks in Turkey. Munich Personal RePEc Archive, MPRA Paper No. 70634 (pp.1-27).

Taylor, B. J. (2009). The financial crisis and the policy responses: an empirical analysis of what went wrong. Working Paper 14631.

Thorsten, B., Asli, D. K., \& Ouarda, M. (2013). Islamic vs. conventional banking: Business model, efficiency and stability. Journal of Banking \& Finance, 37(2), 433-447.

Trabelsi, L., Bahloul, S., \& Mathlouthi, F. (2019). Performance analysis of Islamic and conventional portfolios: The emerging markets case. Borsa Istanbul Review, 1-7.

Wymeersch, E. (2008). Corporate Governance and Financial Stability. Financial Law Institute Working Paper No. WP-11 (pp.1-16). 


\section{Appendix}

Table 7. ADF test of the DJ Asia Pacific Index

Null Hypothesis: PT has a unit root

\begin{tabular}{|c|c|c|c|c|}
\hline & & $\begin{array}{l}\text { Exogenous: } \\
\text { Constant }\end{array}$ & $\begin{array}{l}\text { Exogenous: } \\
\text { Constant, Linear } \\
\text { Trend }\end{array}$ & $\begin{array}{l}\text { Exogenous: } \\
\text { None }\end{array}$ \\
\hline & & $\begin{array}{l}\text { Lag Length: } 0 \\
\text { (Automatic - based } \\
\text { on } \\
\text { maxlag=29) }\end{array}$ & $\begin{array}{l}\text { Lag Length: } 0 \\
\text { (Automatic - based } \\
\text { on SIC, maxlag=29) }\end{array}$ & $\begin{array}{l}\text { Lag Length: } 0 \\
\text { (Automatic - } \\
\text { based on SIC, } \\
\text { maxlag=29) }\end{array}$ \\
\hline & & t-Statistic & t-Statistic & t-Statistic \\
\hline $\begin{array}{l}\text { Augmented } \\
\text { test statistic }\end{array}$ & Dickey-Fuller & -2.054254 & -2.007966 & 0.211750 \\
\hline \multirow{3}{*}{$\begin{array}{l}\text { Test } \\
\text { values: }\end{array}$} & $11 \%$ level & -3.431954 & -3.960553 & -2.565595 \\
\hline & $5 \%$ level & -2.862134 & -3.411036 & -1.940911 \\
\hline & $10 \%$ level & -2.567130 & -3.127335 & -1.616641 \\
\hline
\end{tabular}

Table 8. ADF test of the DJ Emerging Markets Index

Null Hypothesis: PT has a unit root

\begin{tabular}{|c|c|c|c|c|}
\hline & & $\begin{array}{l}\text { Exogenous: } \\
\text { Constant }\end{array}$ & $\begin{array}{l}\text { Exogenous: } \\
\text { Constant, Linear } \\
\text { Trend }\end{array}$ & Exogenous: None \\
\hline & & $\begin{array}{l}\text { Lag Length: } 3 \\
\text { (Automatic } \\
\text { based on SIC, } \\
\text { maxlag=29) }\end{array}$ & $\begin{array}{l}\text { Lag Length: } 3 \\
\text { (Automatic - based } \\
\text { on SIC, maxlag=29) }\end{array}$ & $\begin{array}{l}\text { Lag Length: } 3 \\
\text { (Automatic - based } \\
\text { on SIC, maxlag=29) }\end{array}$ \\
\hline & & t-Statistic & t-Statistic & t-Statistic \\
\hline $\begin{array}{l}\text { Augmented } \\
\text { test statistic }\end{array}$ & Dickey-Fuller & -1.778571 & -1.693255 & 0.165973 \\
\hline \multirow{3}{*}{$\begin{array}{l}\text { Test critical } \\
\text { values: }\end{array}$} & $1 \%$ level & -3.431956 & -3.960555 & -2.565596 \\
\hline & $5 \%$ level & -2.862135 & -3.411037 & -1.940911 \\
\hline & $10 \%$ level & -2.567130 & -3.127335 & -1.616641 \\
\hline
\end{tabular}


Table 9. ADF test of the DJ Europe Index 2020, Vol. 10, No. 1

Null Hypothesis: PT has a unit root

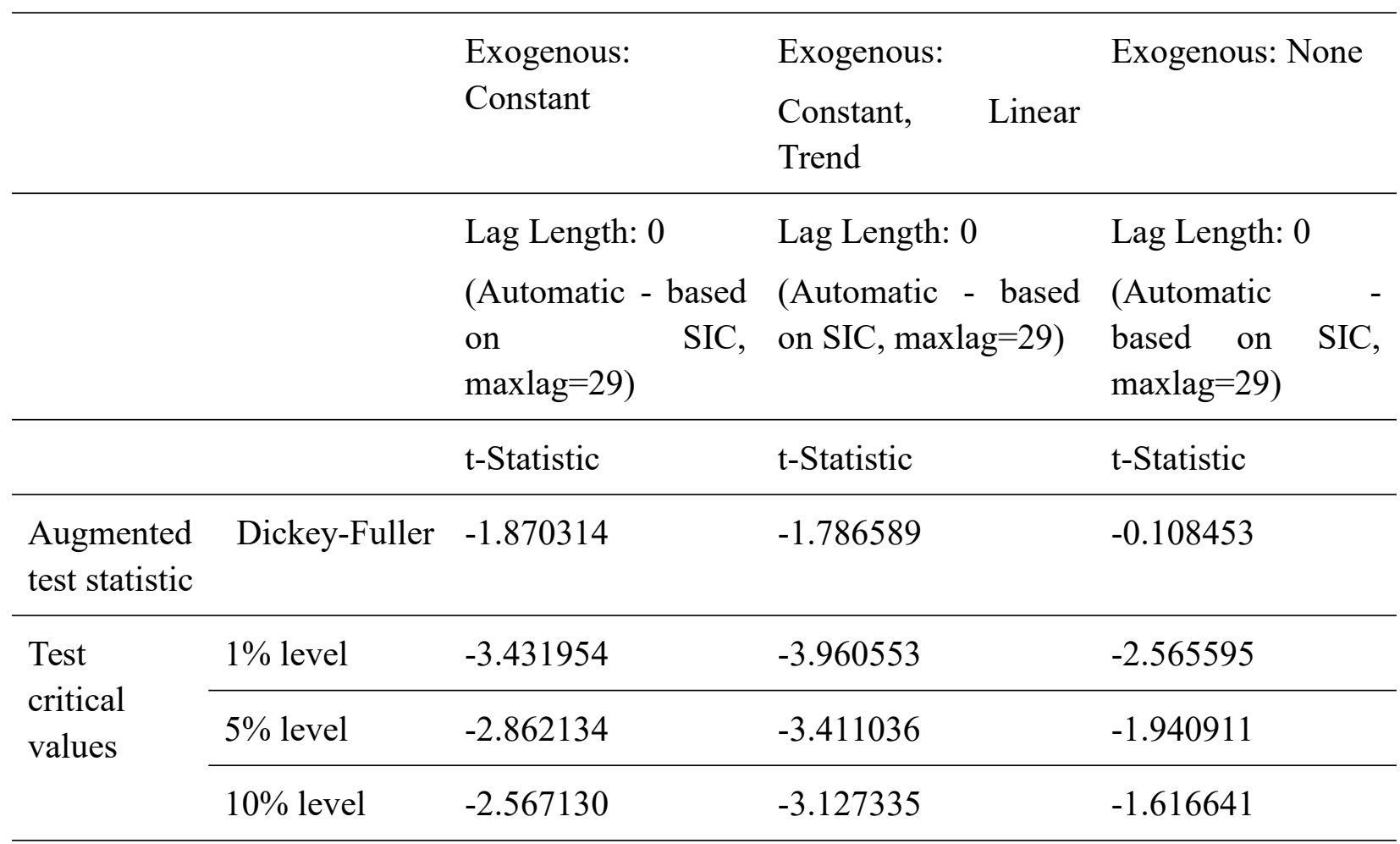

Table 10. ADF test of the DJ U.S Index

Null Hypothesis: PT has a unit root

\begin{tabular}{|c|c|c|c|c|}
\hline & & $\begin{array}{l}\text { Exogenous: } \\
\text { Constant }\end{array}$ & $\begin{array}{l}\text { Exogenous: } \\
\text { Constant, } \\
\text { Trend }\end{array}$ & Exogenous: None \\
\hline & & $\begin{array}{l}\text { Lag Length: } 1 \\
\text { (Automatic - } \\
\text { based on SIC, } \\
\text { maxlag=29) }\end{array}$ & $\begin{array}{l}\text { Lag Length: } 1 \\
\text { (Automatic - based on } \\
\text { SIC, maxlag=29) }\end{array}$ & $\begin{array}{l}\text { Lag Length: } 1 \\
\text { (Automatic - based } \\
\text { on SIC, maxlag=29) }\end{array}$ \\
\hline & & $\mathrm{t}$-Statistic & $\mathrm{t}$-Statistic & t-Statistic \\
\hline $\begin{array}{l}\text { Augmented } \\
\text { test statistic }\end{array}$ & Dickey-Fuller & -0.306389 & -1.972896 & 1.078677 \\
\hline \multirow{3}{*}{$\begin{array}{l}\text { Test } \\
\text { critical } \\
\text { values: }\end{array}$} & $1 \%$ level & -3.431955 & -3.960553 & -2.565596 \\
\hline & $5 \%$ level & -2.862134 & -3.411036 & -1.940911 \\
\hline & $10 \%$ level & -2.567130 & -3.127335 & -1.616641 \\
\hline
\end{tabular}


Table 11. ADF test of the Dow Jones Global Index

Null Hypothesis: PT has a unit root

$\begin{array}{lll}\text { Exogenous: } & \text { Exogenous: } & \text { Exogenous: None } \\ \text { Constant } & \text { Constant, } & \text { Linear } \\ & \text { Trend } & \end{array}$

\begin{tabular}{|c|c|c|c|c|}
\hline & & $\begin{array}{l}\text { Lag Length: } 1 \\
\text { (Automatic } \\
\text { based on SIC, } \\
\text { maxlag=29) }\end{array}$ & $\begin{array}{l}\text { Lag Length: } 1 \\
\text { (Automatic - based on } \\
\text { SIC, maxlag=29) }\end{array}$ & $\begin{array}{l}\text { Lag Length: } 1 \\
\text { (Automatic - based } \\
\text { on SIC, maxlag=29) }\end{array}$ \\
\hline & & t-Statistic & t-Statistic & t-Statistic \\
\hline $\begin{array}{l}\text { Augmented I } \\
\text { test statistic }\end{array}$ & Dickey-Fuller & -1.367108 & -2.106555 & 0.486542 \\
\hline \multirow{3}{*}{$\begin{array}{l}\text { Test critical } \\
\text { values }\end{array}$} & $1 \%$ level & -3.431955 & -3.960553 & -2.565596 \\
\hline & $5 \%$ level & -2.862134 & -3.411036 & -1.940911 \\
\hline & $10 \%$ level & -2.567130 & -3.127335 & -1.616641 \\
\hline
\end{tabular}

Table 12. ADF test of the DJIM Asia Pacific Index

Null Hypothesis: PT has a unit root

\begin{tabular}{|c|c|c|c|c|}
\hline & & $\begin{array}{l}\text { Exogenous: } \\
\text { Constant }\end{array}$ & $\begin{array}{l}\text { Exogenous: } \\
\text { Constant, Linear } \\
\text { Trend }\end{array}$ & Exogenous: None \\
\hline & & $\begin{array}{l}\text { Lag Length: } 0 \\
\text { (Automatic } \\
\text { based on SIC, } \\
\text { maxlag=29) }\end{array}$ & $\begin{array}{l}\text { Lag Length: } 0 \\
\text { (Automatic - based } \\
\text { on SIC, maxlag=29) }\end{array}$ & $\begin{array}{l}\text { Lag Length: } 0 \\
\text { (Automatic - based } \\
\text { on SIC, maxlag=29) }\end{array}$ \\
\hline & & t-Statistic & t-Statistic & t-Statistic \\
\hline $\begin{array}{l}\text { Augmented } \\
\text { test statistic }\end{array}$ & Dickey-Fuller & -1.894178 & -2.289213 & 0.208902 \\
\hline \multirow{3}{*}{$\begin{array}{l}\text { Test } \\
\text { critical } \\
\text { values }\end{array}$} & $1 \%$ level & -3.431954 & -3.960553 & -2.565595 \\
\hline & $5 \%$ level & -2.862134 & -3.411036 & -1.940911 \\
\hline & $10 \%$ level & -2.567130 & -3.127335 & -1.616641 \\
\hline
\end{tabular}


Table 13. ADF test of the DJIM Emerging Markets Index

Null Hypothesis: PT has a unit root

$$
\begin{array}{ll}
\text { Exogenous: } & \text { Exogenous: } \quad \text { Exogenous: None } \\
\text { Constant } & \text { Constant, Linear } \\
& \text { Trend }
\end{array}
$$

\begin{tabular}{llllll}
\hline & & $\begin{array}{l}\text { Lag Length: } \\
\text { (Automatic } \\
\text { based on SIC, } \\
\text { maxlag=29) }\end{array}$ & $\begin{array}{l}\text { Lag Length: } \\
\text { (Automatic } \\
\text { maxlag=29) }\end{array}$ & $\begin{array}{l}\text { Lag Length: } 1 \\
\text { (Automatic - based }\end{array}$ \\
& & t-Statistic & t-Statistic & t-Statistic \\
\hline $\begin{array}{l}\text { Augmented } \\
\text { statistic }\end{array}$ & Dickey-Fuller test & -1.812145 & -1.762428 & -0.127494 \\
\hline $\begin{array}{l}\text { Test } \\
\text { critical } \\
\text { values }\end{array}$ & $1 \%$ level & -3.431955 & -3.960553 & -2.565596 \\
\cline { 2 - 6 } & $5 \%$ level & -2.862134 & -3.411036 & -1.940911 \\
\hline
\end{tabular}

Table 14. ADF test of the DJIM Europe Index

Null Hypothesis: PT has a unit root

Exogenous: Exogenous: Exogenous: None

Constant Constant, Linear

Trend

\begin{tabular}{llllll}
\hline & & $\begin{array}{l}\text { Lag Length: } \\
\text { (Automatic } \\
\text { based on SIC, } \\
\text { maxlag=29) }\end{array}$ & $\begin{array}{l}\text { Lag Length: } \\
\text { (Automatic - based } \\
\text { maxlag=29) }\end{array}$ & $\begin{array}{l}\text { Lag Length: } 0 \\
\text { (Automatic - based }\end{array}$ \\
& & t-Statistic & t-Statistic & t-Statistic \\
\hline $\begin{array}{l}\text { Augmented } \\
\text { test statistic }\end{array}$ & Dickey-Fuller & -1.856490 & -2.310641 & 0.055890 \\
\hline $\begin{array}{l}\text { Test critical } \\
\text { values: }\end{array}$ & $1 \%$ level & -3.431954 & -3.960553 & -2.565595 \\
\cline { 2 - 6 } & $5 \%$ level & -2.862134 & -3.411036 & -1.940911 \\
\cline { 2 - 6 } & $10 \%$ level & -2.567130 & -3.127335 & -1.616641 \\
\hline
\end{tabular}


Table 15. ADF test of the DJIM U.S. Index

Null Hypothesis: PT has a unit root

\begin{tabular}{|c|c|c|c|c|}
\hline & & \multirow{2}{*}{$\begin{array}{l}\text { Exogenous: } \\
\text { Constant }\end{array}$} & Exogenous: & \multirow[t]{2}{*}{ Exogenous: None } \\
\hline & & & $\begin{array}{l}\text { Constant, Linear } \\
\text { Trend }\end{array}$ & \\
\hline & & $\begin{array}{l}\text { Lag Length: } 1 \\
\text { (Automatic - based }\end{array}$ & Lag Length: 1 & Lag Length: 1 \\
\hline & & $\begin{array}{l}\text { on } \\
\text { maxlag=29) }\end{array}$ & $\begin{array}{l}\text { (Automatic - based } \\
\text { on } \\
\text { maxlag=29) }\end{array}$ & $\begin{array}{l}\text { (Automatic - } \\
\text { based on SIC, } \\
\text { maxlag=29) }\end{array}$ \\
\hline & & t-Statistic & $\mathrm{t}$-Statistic & $\mathrm{t}$-Statistic \\
\hline $\begin{array}{l}\text { Augmented I } \\
\text { statistic }\end{array}$ & Dickey-Fuller test & -0.169842 & -2.498241 & 1.182187 \\
\hline \multirow{3}{*}{$\begin{array}{l}\text { Test critical } \\
\text { values: }\end{array}$} & $1 \%$ level & -3.431955 & -3.960553 & -2.565596 \\
\hline & $5 \%$ level & -2.862134 & -3.411036 & -1.940911 \\
\hline & $10 \%$ level & -2.567130 & -3.127335 & -1.616641 \\
\hline
\end{tabular}

Table 16. ADF test of the DJIM World Index

Null Hypothesis: PT has a unit root

\begin{tabular}{|c|c|c|c|c|}
\hline & & $\begin{array}{l}\text { Exogenous: } \\
\text { Constant }\end{array}$ & $\begin{array}{l}\text { Exogenous: } \\
\text { Constant, Linear } \\
\text { Trend }\end{array}$ & Exogenous: None \\
\hline & & $\begin{array}{l}\text { Lag Length: } 1 \\
\text { (Automatic } \\
\text { based on SIC, } \\
\text { maxlag=29) }\end{array}$ & $\begin{array}{l}\text { Lag Length: } 1 \\
\text { (Automatic - based } \\
\text { on SIC, maxlag=29) }\end{array}$ & $\begin{array}{l}\text { Lag Length: } 1 \\
\text { (Automatic - based } \\
\text { on SIC, maxlag=29) }\end{array}$ \\
\hline & & t-Statistic & $\mathrm{t}$-Statistic & t-Statistic \\
\hline \multirow{2}{*}{\multicolumn{2}{|c|}{$\begin{array}{l}\text { Augmented } \\
\text { Dickey-Fuller } \\
\text { statistic }\end{array}$}} & -1.062873 & -2.667920 & 0.647901 \\
\hline & & & & \\
\hline \multirow{3}{*}{$\begin{array}{l}\text { Test } \\
\text { critical } \\
\text { values: }\end{array}$} & $1 \%$ level & -3.431955 & -3.960553 & -2.565596 \\
\hline & $5 \%$ level & -2.862134 & -3.411036 & -1.940911 \\
\hline & $10 \%$ level & -2.567130 & -3.127335 & -1.616641 \\
\hline
\end{tabular}


Table 17. ADF Test of the yields of the DJ Asia Pacific Index

Null Hypothesis: RI has a unit root

$\begin{array}{ll}\text { Exogenous: } & \text { Exogenous: } \quad \text { Exogenous: None } \\ \text { Constant } & \text { Constant, Linear } \\ & \text { Trend }\end{array}$

\begin{tabular}{llllll}
\hline & & $\begin{array}{l}\text { Lag Length: } \\
\text { (Automatic } \\
\text { based on SIC, } \\
\text { maxlag=29) }\end{array}$ & $\begin{array}{l}\text { Lag Length: } \\
\text { (Automatic - based } \\
\text { maxlag=29) }\end{array}$ & $\begin{array}{l}\text { Lag Length: 0 } \\
\text { (Automatic - based } \\
\text { on SIC, maxlag=29) }\end{array}$ \\
\hline \multirow{2}{*}{$\begin{array}{l}\text { Augmented } \\
\text { test statistic }\end{array}$} & Dickey-Fuller & -60.08592 & -60.09288 & -60.08386 \\
\hline $\begin{array}{l}\text { Test critical } \\
\text { values }\end{array}$ & $1 \%$ level & -3.431954 & -3.960553 & -2.565595 \\
\cline { 2 - 6 } & $5 \%$ level & -2.862134 & -3.411036 & -1.940911 \\
\cline { 2 - 6 } & $10 \%$ level & -2.567130 & -3.127335 & -1.616641 \\
\hline
\end{tabular}

Table 18. ADF Test of the yields of the DJ Emerging Markets Index

Null Hypothesis: RI has a unit root

\begin{tabular}{|c|c|c|c|c|}
\hline & & $\begin{array}{l}\text { Exogenous: } \\
\text { Constant }\end{array}$ & $\begin{array}{l}\text { Exogenous: } \\
\text { Constant, Linear } \\
\text { Trend }\end{array}$ & $\begin{array}{l}\text { Exogenous: } \\
\text { None }\end{array}$ \\
\hline & & $\begin{array}{l}\text { Lag Length: } 2 \\
\text { (Automatic - based } \\
\text { on SIC, maxlag=29) }\end{array}$ & $\begin{array}{l}\text { Lag Length: } 2 \\
\text { (Automatic - based } \\
\text { on } \\
\text { maxlag=29) }\end{array}$ & $\begin{array}{l}\text { Lag Length: } 2 \\
\text { (Automatic - } \\
\text { based on SIC, } \\
\text { maxlag=29) }\end{array}$ \\
\hline & & t-Statistic & t-Statistic & t-Statistic \\
\hline $\begin{array}{l}\text { Augmented } \\
\text { test statistic }\end{array}$ & Dickey-Fuller & -32.56718 & -32.58618 & -32.55081 \\
\hline \multirow{3}{*}{$\begin{array}{l}\text { Test critical } \\
\text { values }\end{array}$} & $1 \%$ level & -3.431955 & -3.960554 & -2.565596 \\
\hline & $5 \%$ level & -2.862135 & -3.411037 & -1.940911 \\
\hline & $10 \%$ level & -2.567130 & -3.127335 & -1.616641 \\
\hline
\end{tabular}


Table 19. ADF Test of the yields of the DJ Europe Index

Null Hypothesis: RI has a unit root

$\begin{array}{ll}\text { Exogenous: } & \text { Exogenous: } \\ \text { Constant } & \text { Constant, Lxogenous: None } \\ & \text { Trend }\end{array}$

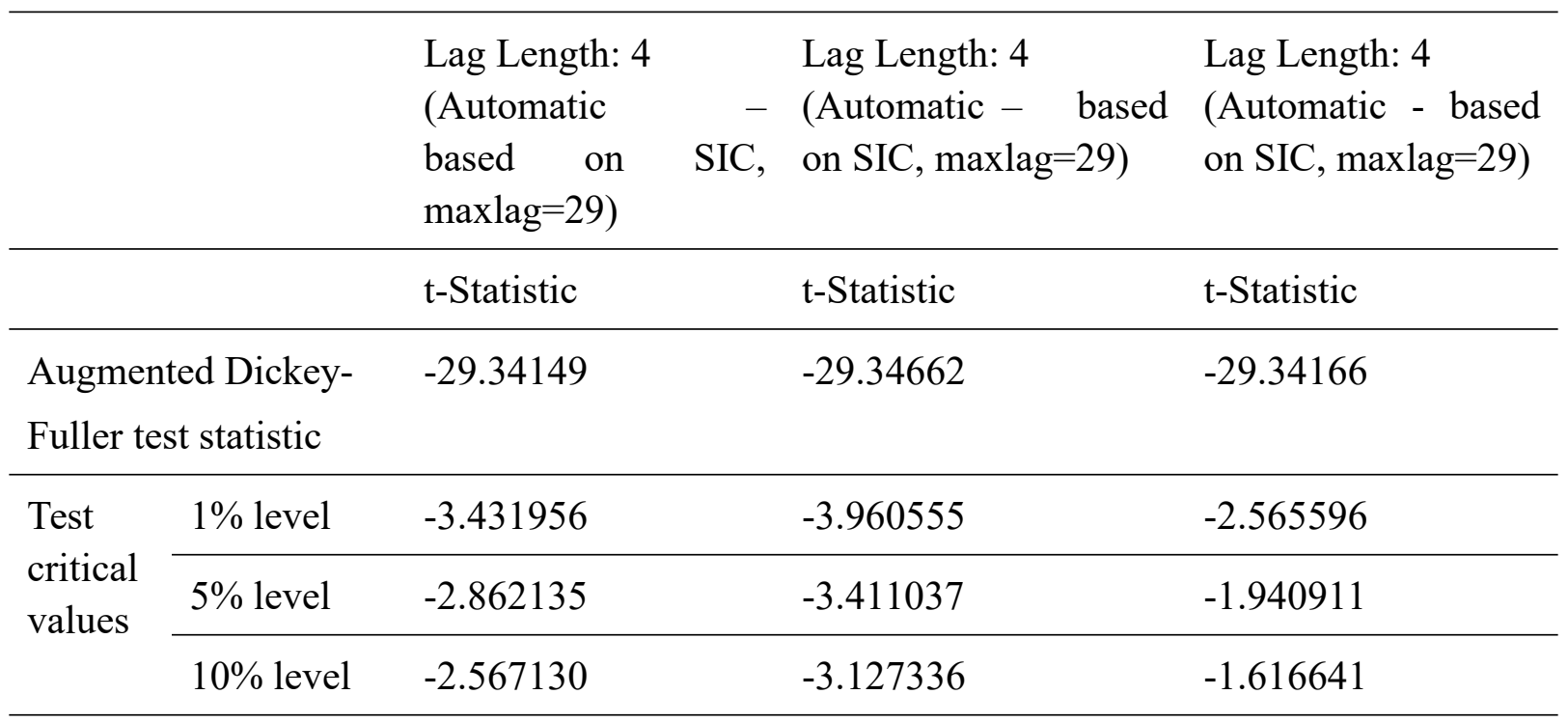

Table 20. ADF Test of the yields of the DJ U.S. Index

Null Hypothesis: RI has a unit root

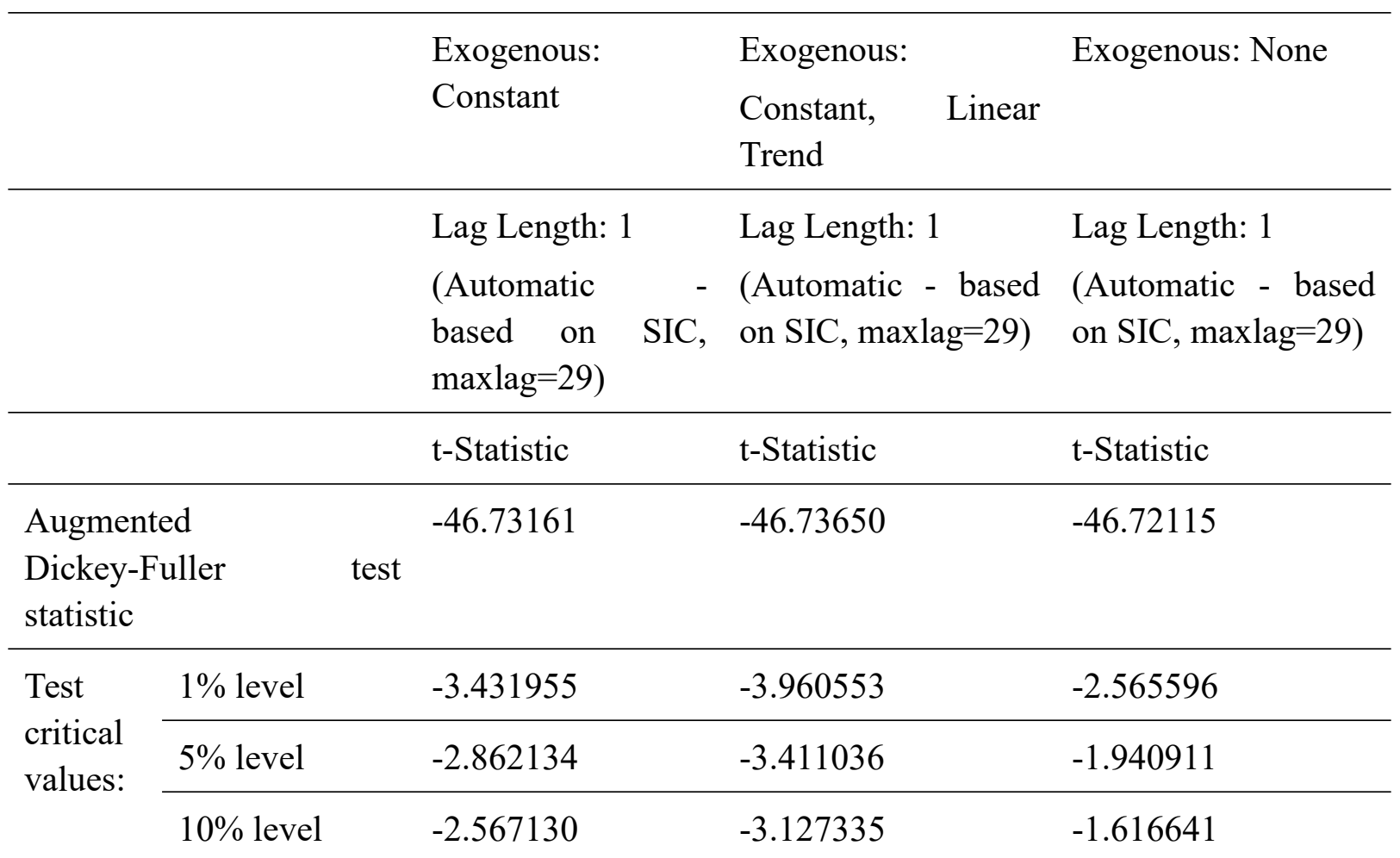


Table 21. ADF Test of the yields of the Dow Jones Global Index

Null Hypothesis: RI has a unit root

$\begin{array}{lll}\text { Exogenous: Constant } & \text { Exogenous: } \\ & \text { Constant, Linear } \\ & \text { Trend }\end{array}$

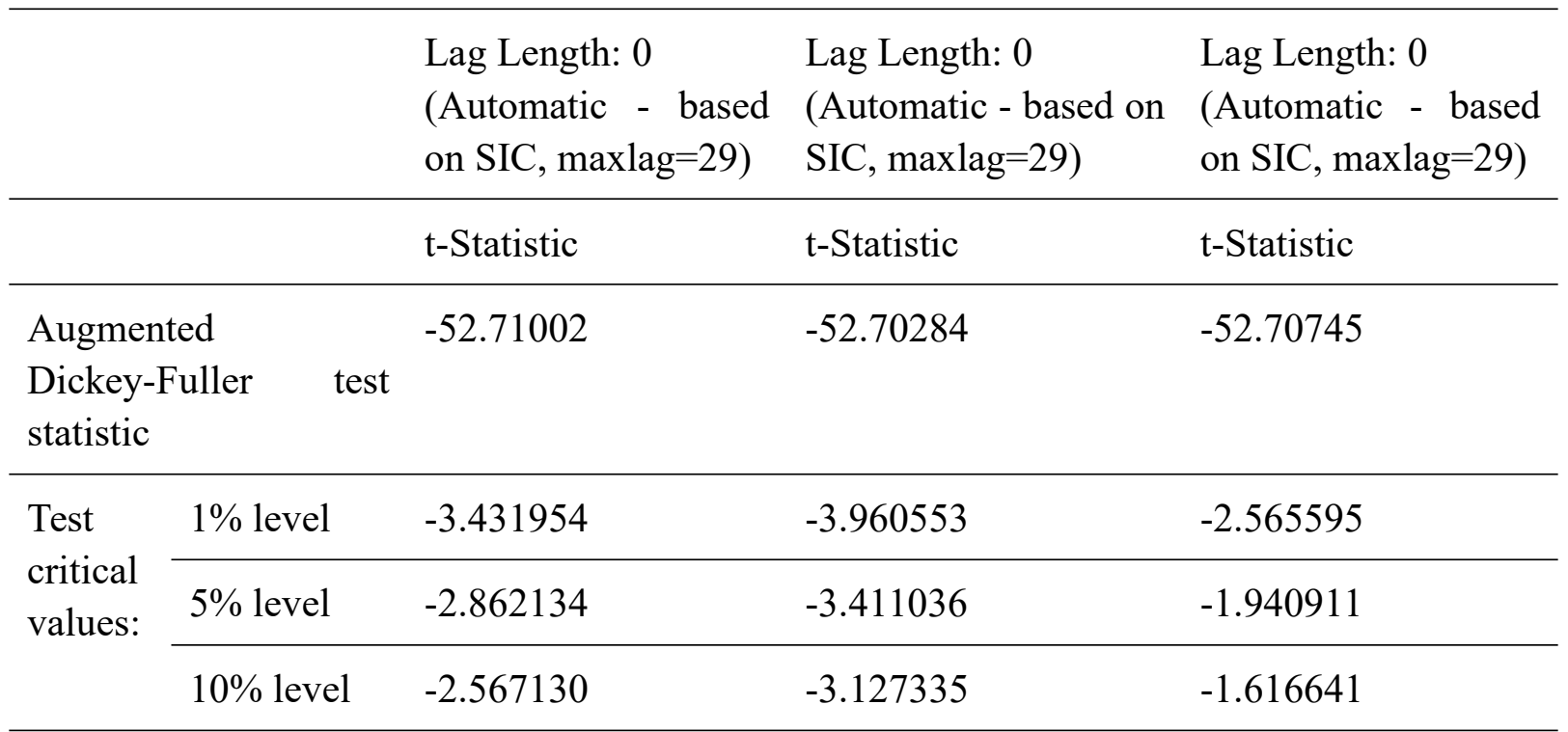

Table 22. ADF Test of the yields of the DJIM Asia Pacific Index

Null Hypothesis: RI has a unit root

\begin{tabular}{|c|c|c|c|c|}
\hline & & $\begin{array}{l}\text { Exogenous: } \\
\text { Constant }\end{array}$ & $\begin{array}{l}\text { Exogenous: } \\
\text { Constant, Linear Trend }\end{array}$ & Exogenous: None \\
\hline & & $\begin{array}{l}\text { Lag Length: } 0 \\
\text { (Automatic - based } \\
\text { on SIC, maxlag=29) }\end{array}$ & $\begin{array}{l}\text { Lag Length: } 0 \\
\text { (Automatic - based on } \\
\text { SIC, maxlag=29) }\end{array}$ & $\begin{array}{l}\text { Lag Length: } 0 \\
\text { (Automatic - based } \\
\text { on SIC, maxlag=29) }\end{array}$ \\
\hline & & t-Statistic & $\mathrm{t}-$ Statistic & t-Statistic \\
\hline $\begin{array}{l}\text { Augmer } \\
\text { Dickey- } \\
\text { statistic }\end{array}$ & uller test & -59.07566 & -59.07275 & -59.07676 \\
\hline \multirow{3}{*}{$\begin{array}{l}\text { Test } \\
\text { critical } \\
\text { values: }\end{array}$} & $1 \%$ level & -3.431954 & -3.960553 & -2.565595 \\
\hline & $5 \%$ level & -2.862134 & -3.411036 & -1.940911 \\
\hline & $10 \%$ level & -2.567130 & -3.127335 & -1.616641 \\
\hline
\end{tabular}


Table 23. ADF Test of the yields of the DJIM Emerging Markets Index

Null Hypothesis: RI has a unit root

$\begin{array}{ll}\text { Exogenous: } & \text { Exogenous: } \quad \text { Exogenous: None } \\ \text { Constant } & \text { Constant, Linear } \\ & \text { Trend }\end{array}$

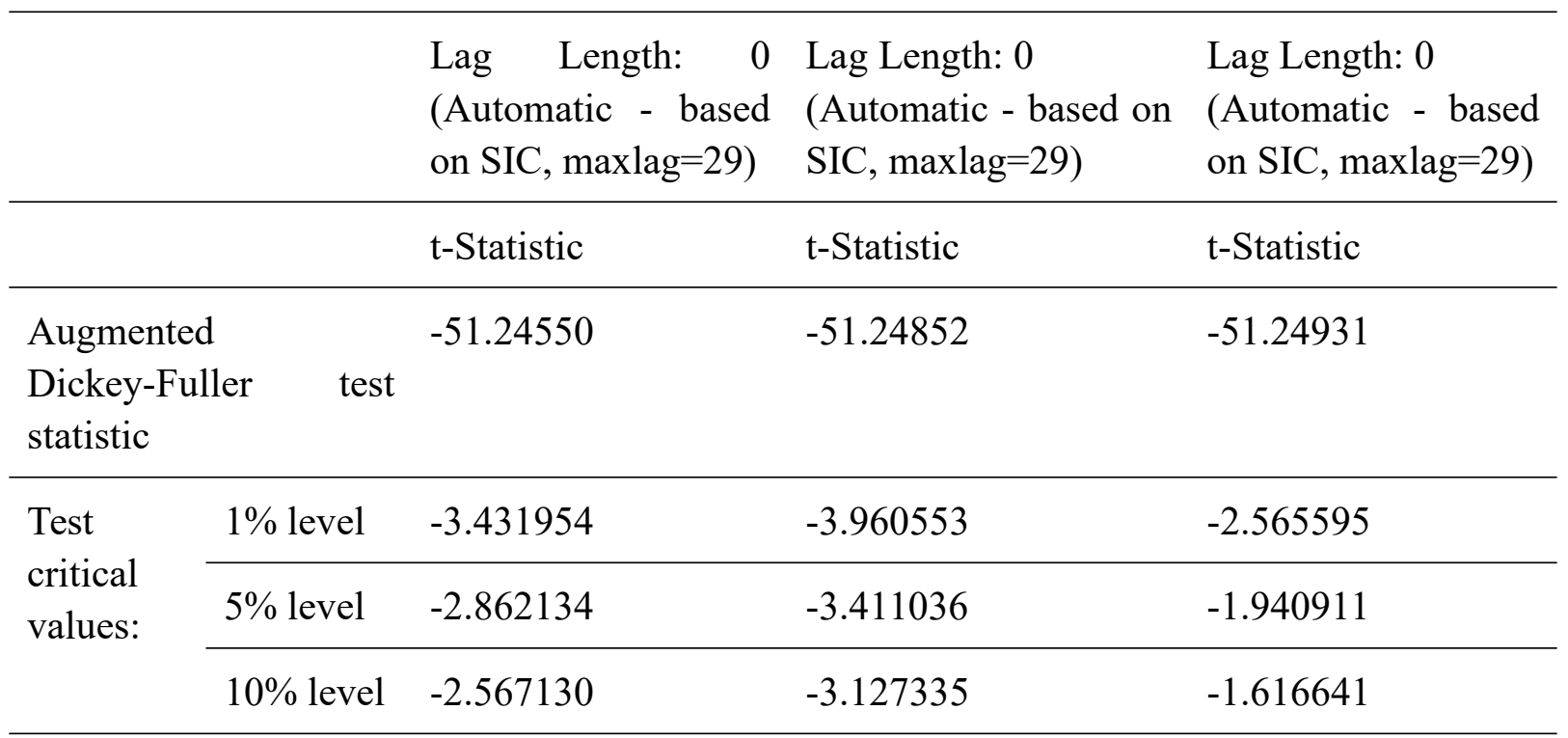

Table 24. ADF Test of the yields of the DJIM Europe Index

Null Hypothesis: RI has a unit root

$\begin{array}{ll}\text { Exogenous: Constant } & \text { Exogenous: Exogenous: None } \\ & \text { Constant, Linear } \\ & \text { Trend }\end{array}$

\begin{tabular}{lllll}
\hline & $\begin{array}{l}\text { Lag Length: } \\
\text { (Automatic }- \text { based } \\
\text { on SIC, maxlag=29) }\end{array}$ & $\begin{array}{l}\text { Lag Length: } 4 \\
\text { (Automatic }\end{array}$ & $\begin{array}{l}\text { Lag Length: } 4 \\
\text { on SIC, maxlag=29) }\end{array}$ & $\begin{array}{l}\text { (Automatic - based } \\
\text { on SIC, maxlag=29) }\end{array}$ \\
\hline & t-Statistic & t-Statistic & t-Statistic \\
\hline $\begin{array}{l}\text { Augmented } \\
\begin{array}{l}\text { Dickey-Fuller } \\
\text { statistic }\end{array}\end{array}$ & -29.26205 & -29.26215 & -29.25789 \\
\hline $\begin{array}{l}\text { Test } \\
\text { critical } \\
\text { values: }\end{array}$ & $1 \%$ level & -3.431956 & & \\
\cline { 2 - 5 } & $5 \%$ level & -2.862135 & -3.960555 & -2.565596 \\
\hline
\end{tabular}


Table 25. ADF Test of the yields of the DJIM U.S. Index

Null Hypothesis: RI has a unit root

$$
\text { Exogenous: Constant Exogenous: Exogenous: None }
$$

Constant, Linear

Trend

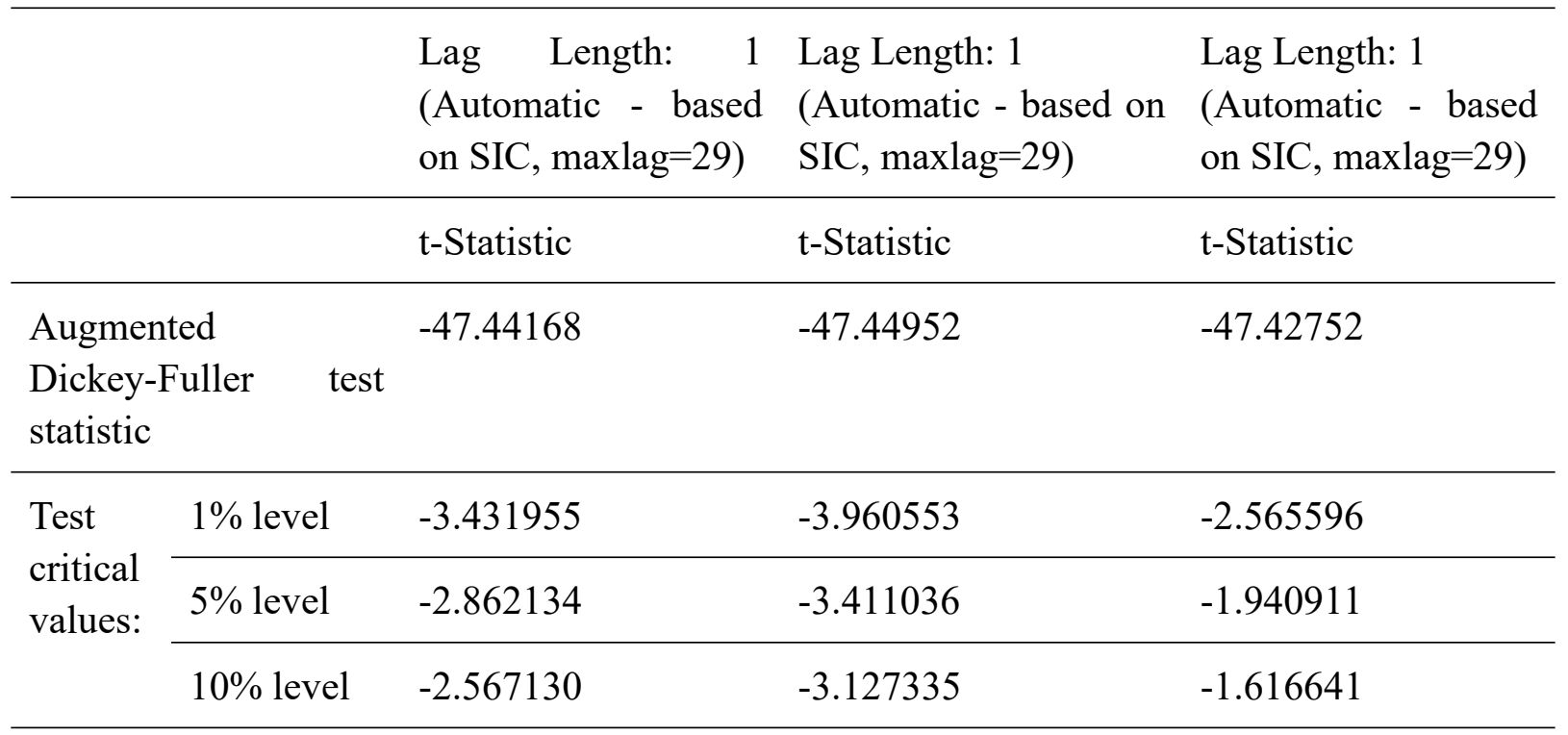

Table 26. ADF Test of the yields of the DJIM World Index

Null Hypothesis: RI has a unit root

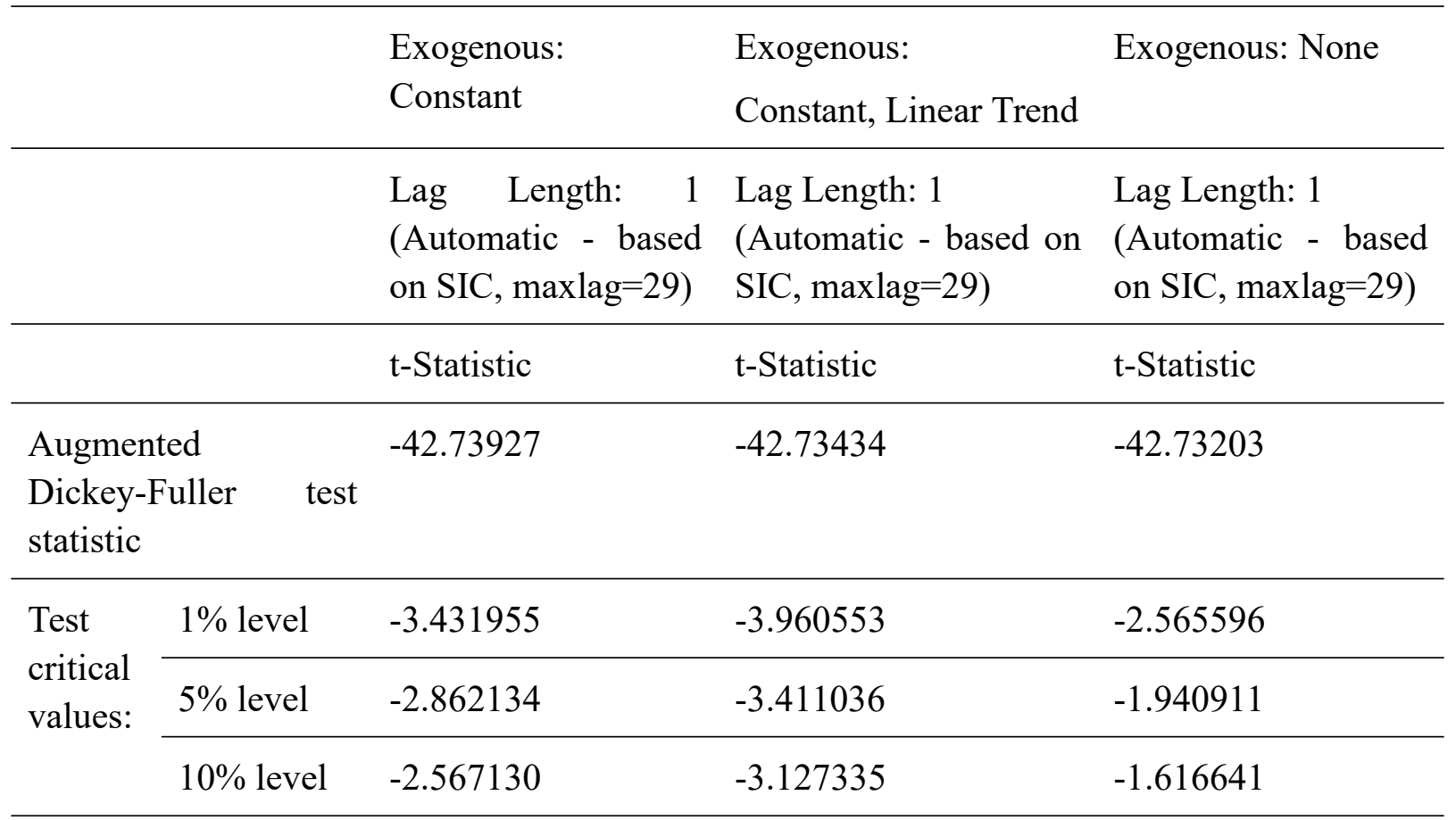


Table 29. Results of the White's test of conventional indices

$$
\begin{array}{llllll} 
& & & & \text { Scaled } & \\
\text { F-statistic } & \begin{array}{l}
\text { Prob. } \\
\text { F(53,3599) }
\end{array} & \text { Obs*R-squared } & \text { Prob. } & \text { Prob. } \\
\text { Chi-Square(53) } & \text { explained } & \text { SS } & \text { Chi-Square(53) }
\end{array}
$$

\begin{tabular}{lllllll}
\hline $\begin{array}{l}\text { DJ Asia } \\
\text { Pacific } \\
\text { Index }\end{array}$ & 8.993628 & 0.0000 & 427.2305 & 0.0000 & 1942.286 & 0.0000 \\
\hline $\begin{array}{l}\text { DJ } \\
\text { Emerging } \\
\text { Markets }\end{array}$ & 38.46104 & 0.0000 & 948.4936 & 0.0000 & 9700.704 & 0.0000 \\
$\begin{array}{l}\text { Index } \\
\text { DJ }\end{array}$ & & & & & & \\
$\begin{array}{l}\text { Europe } \\
\text { Index }\end{array}$ & 46.39759 & 0.0000 & 682.6405 & 0.0000 & 2765.171 & 0.0000 \\
\hline $\begin{array}{l}\text { DJ U.S. } \\
\text { Index }\end{array}$ & 51.79568 & 0.0000 & 1219.617 & 0.0000 & 6263.365 & 0.0000 \\
\hline $\begin{array}{l}\text { Dow } \\
\text { Jones } \\
\text { Global } \\
\text { Index }\end{array}$ & 18.75683 & 0.0000 & 447.7876 & 0.0000 & & \\
\hline
\end{tabular}

Table 30. Results of the White's test of islamic indices

\begin{tabular}{lllllll}
\hline & F-statistic & $\begin{array}{l}\text { Prob. } \\
\text { F(53,3599) }\end{array}$ & $\begin{array}{l}\text { Obs* } \\
\text { R-squared }\end{array}$ & $\begin{array}{l}\text { Prob. } \\
\text { Chi-Square(53) }\end{array}$ & $\begin{array}{l}\text { Scaled } \\
\text { explained SS }\end{array}$ & $\begin{array}{l}\text { Prob. } \\
\text { Chi-Square(53) }\end{array}$ \\
\hline $\begin{array}{l}\text { DJIM Asia } \\
\text { Pacific Index }\end{array}$ & 8.476886 & 0.0000 & 405.4076 & 0.0000 & 2070.406 & 0.0000 \\
\hline $\begin{array}{l}\text { DJIM } \\
\text { Emerging }\end{array}$ & 42.69668 & 0.0000 & 856.2391 & 0.0000 & 4603.380 & 0.0000 \\
$\begin{array}{l}\text { Markets Index } \\
\text { DJIM Europe }\end{array}$ & 56.68235 & 0.0000 & 835.2827 & 0.0000 & 3827.290 & 0.0000 \\
$\begin{array}{l}\text { Index } \\
\text { DJIM U.S. }\end{array}$ & 55.59355 & 0.0000 & 1475.965 & 0.0000 & 7081.359 & 0.0000 \\
$\begin{array}{l}\text { Index } \\
\text { DJIM World }\end{array}$ & 24.32768 & 0.0000 & 542.5816 & 0.0000 & 3280.079 & 0.0000 \\
\hline \begin{tabular}{l} 
Index \\
\hline
\end{tabular} & & & & & & \\
\hline
\end{tabular}


Table 31. Results of the ARCH effect test of conventional indices

$$
\begin{array}{llll}
\text { F-statistic } & \text { Prob. } & \text { Obs* } & \text { Prob. Chi-Square(1) } \\
& F(1,3650) & \text { R-squared } &
\end{array}
$$

\begin{tabular}{|c|c|c|c|c|}
\hline DJ Asia Pacific Index & 50.08470 & 0.0000 & 49.43383 & 0.0000 \\
\hline $\begin{array}{l}\text { DJ Emerging Markets } \\
\text { Index }\end{array}$ & 61.72561 & 0.0000 & 60.73238 & 0.0000 \\
\hline DJ Europe Index & 112.6179 & 0.0000 & 109.3070 & 0.0000 \\
\hline DJ U.S. Index & 174.0723 & 0.0000 & 166.2395 & 0.0000 \\
\hline Dow Jones Global Index & 158.6328 & 0.0000 & 152.1089 & 0.0000 \\
\hline
\end{tabular}

Table 32. Results of the ARCH effect test of Islamic indices

\begin{tabular}{lcccc}
\hline & F-statistic & Probability & $\begin{array}{l}\text { Obs* } \\
\text { R-squared }\end{array}$ & Probability \\
\hline DJIM Asia Pacific Index & 40.69586 & 0.000000 & 40.26871 & 0.000000 \\
\hline DJIM Emerging Markets Index & 136.3052 & 0.000000 & 131.4677 & 0.000000 \\
\hline DJIM Europe Index & 129.5236 & 0.000000 & 125.1523 & 0.000000 \\
\hline DJIM U.S. Index & 158.1737 & 0.000000 & 151.6819 & 0.000000 \\
\hline DJIM World Index & 169.5151 & 0.000000 & 162.0747 & 0.000000 \\
\hline
\end{tabular}

DJ Asia Pacific Index

PT

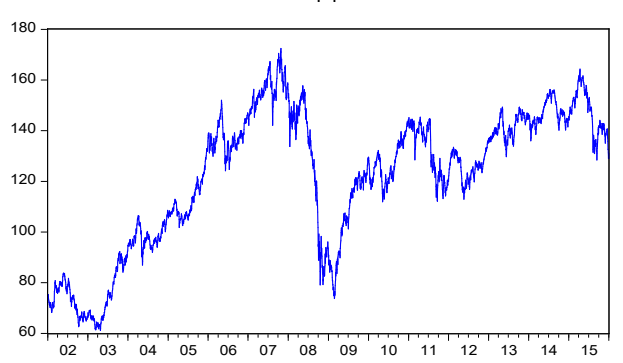

DJIM Asia Pacific Index

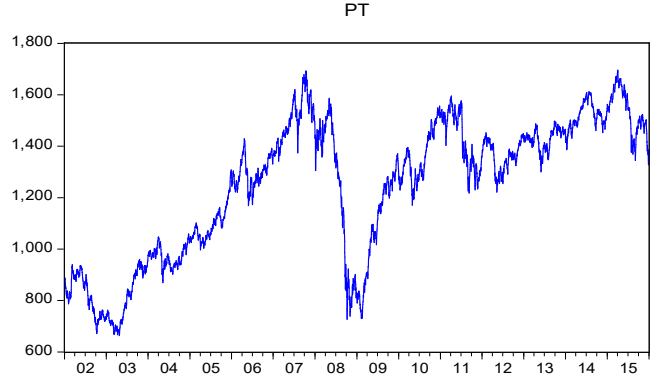


DJ Emerging Markets Index

PT

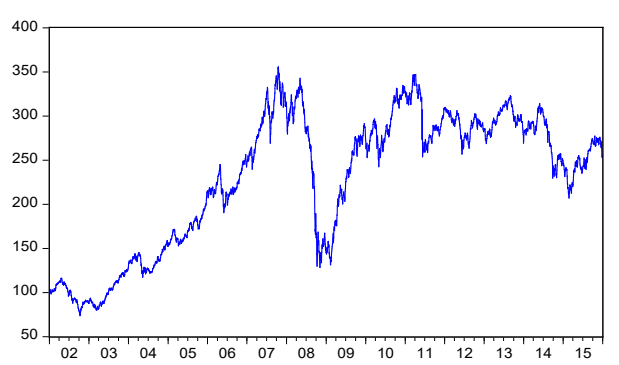

DJ Europe Index

PT

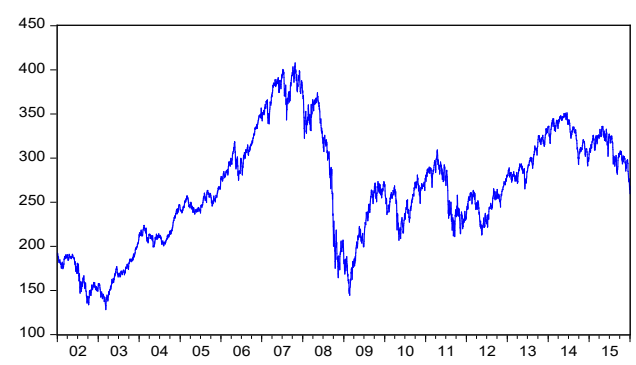

DJ U.S. Index

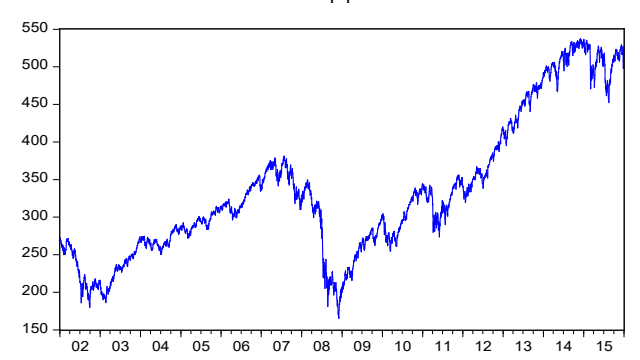

Dow Jones Global Index

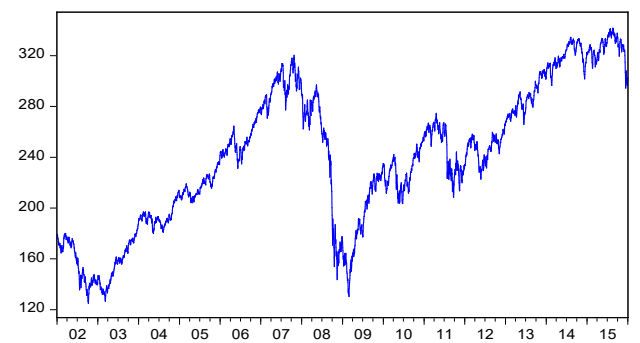

DJIM Emerging Markets Index

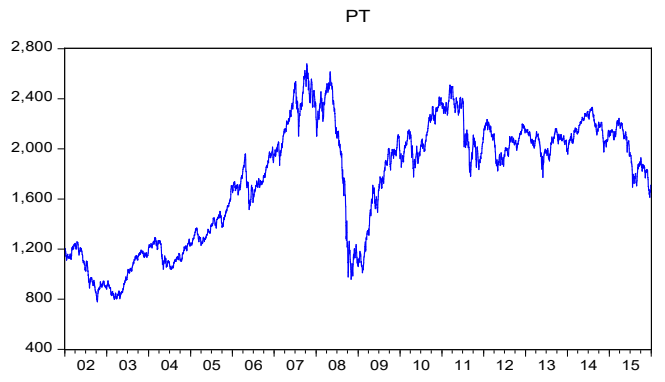

DJIM Europe Index

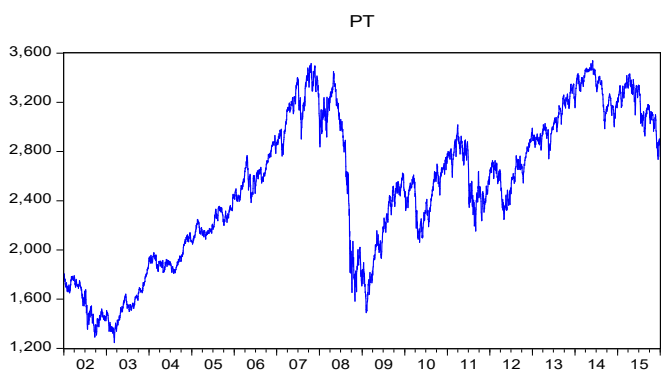

DJIM U.S. Index

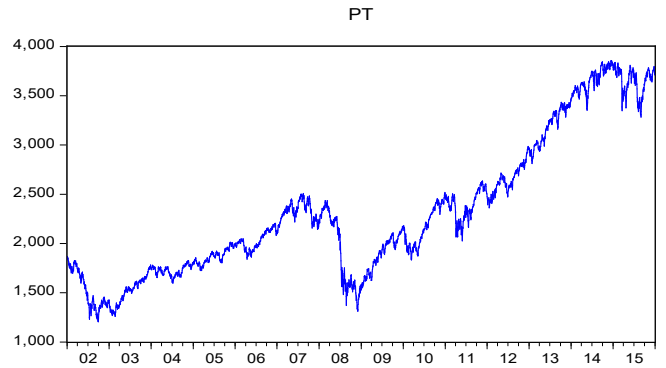

DJIM World Index

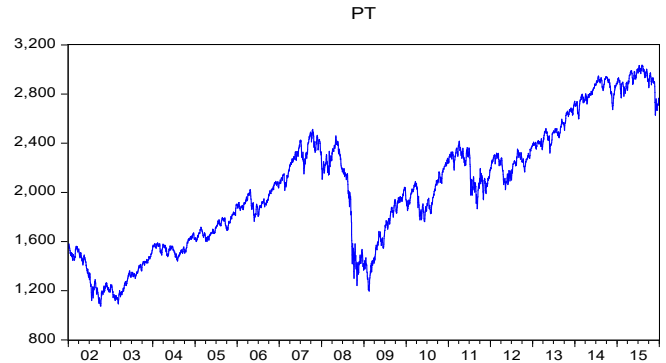

Figure 1. Stock indexes 
DJ Asia Pacific Index

$\mathrm{RI}$

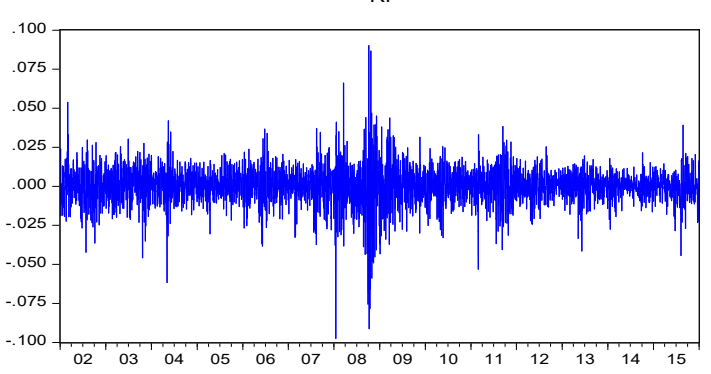

DJ Emerging Markets Index

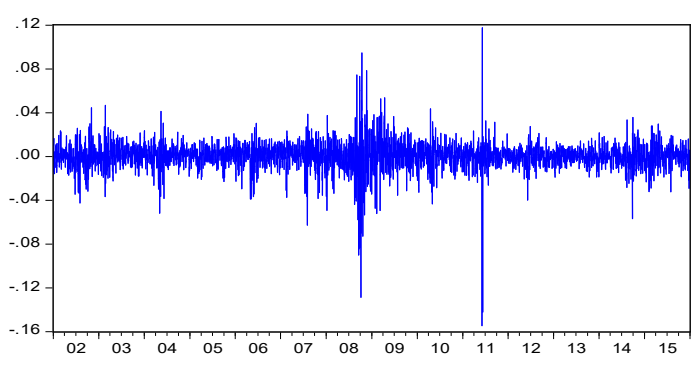

DJ Europe Index

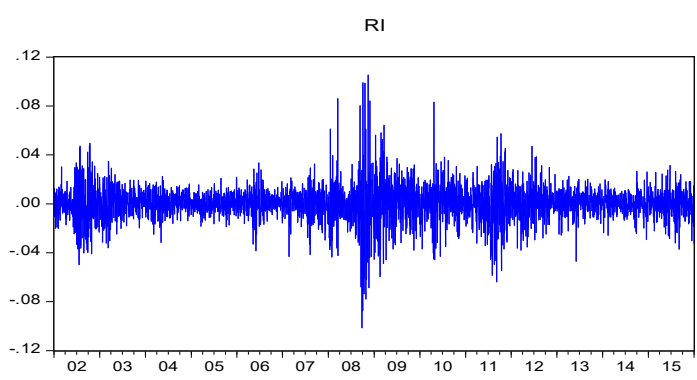

DJ U.S. Index

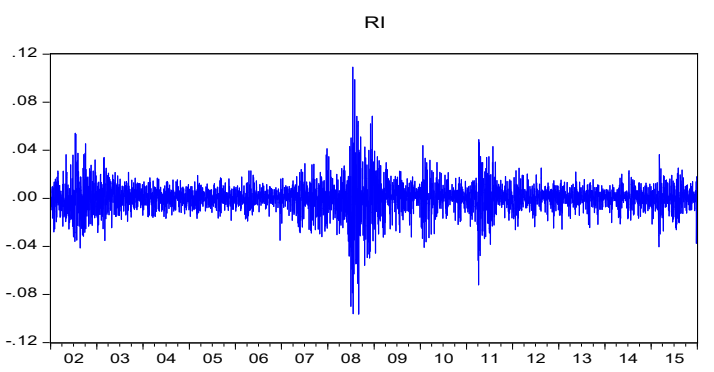

DJIM Asia Pacific Index

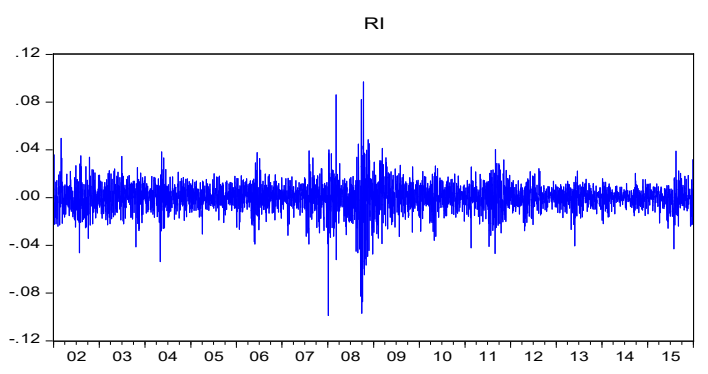

DJIM Emerging Markets Index

RI

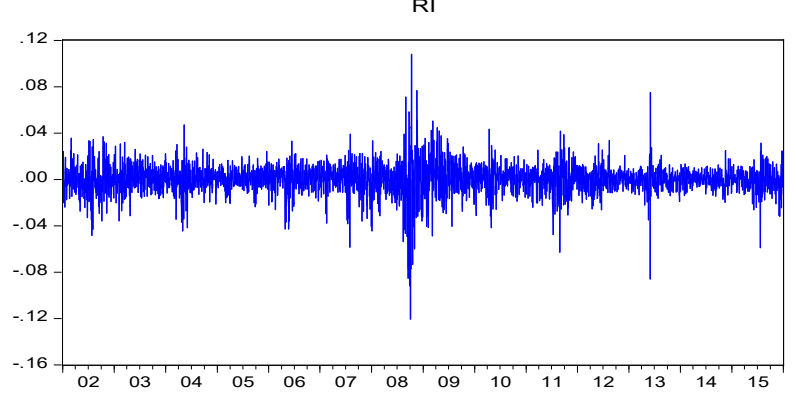

DJIM Europe Index

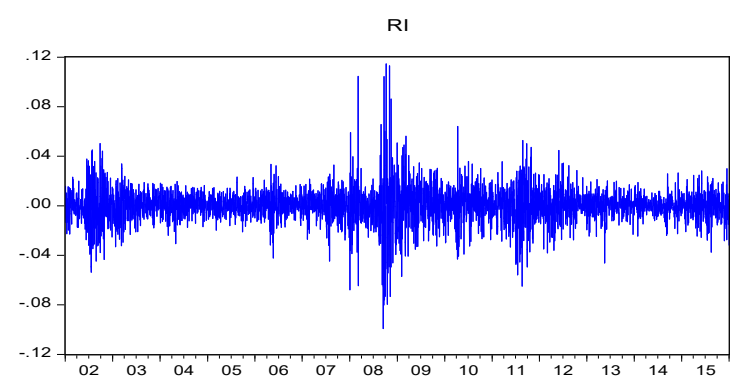

DJIM U.S. Index

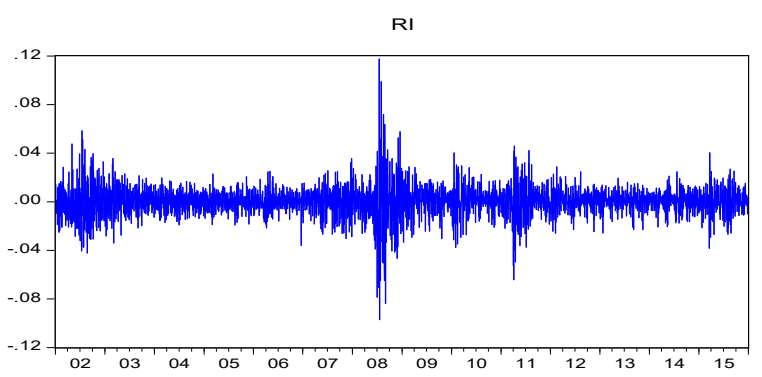


Dow Jones Global Index

RI

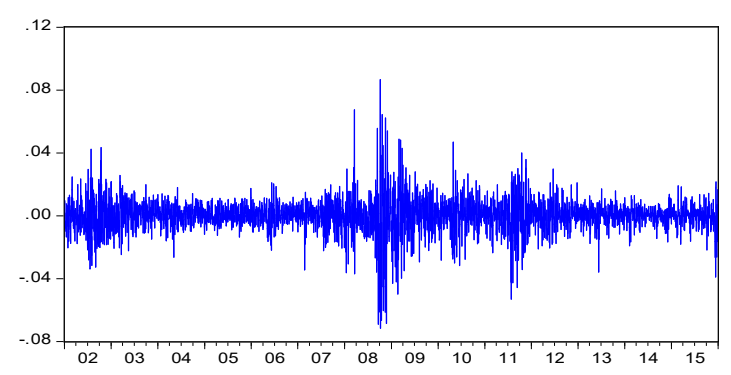

\section{DJIM World Index}

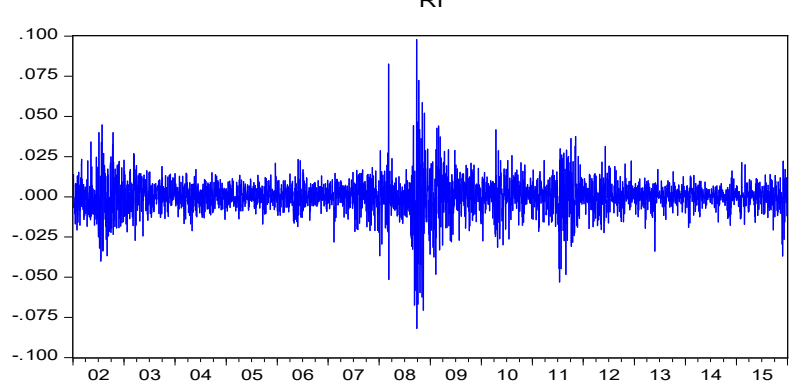

Figure 2. Yields on stock market indices

Asia Pacific Index

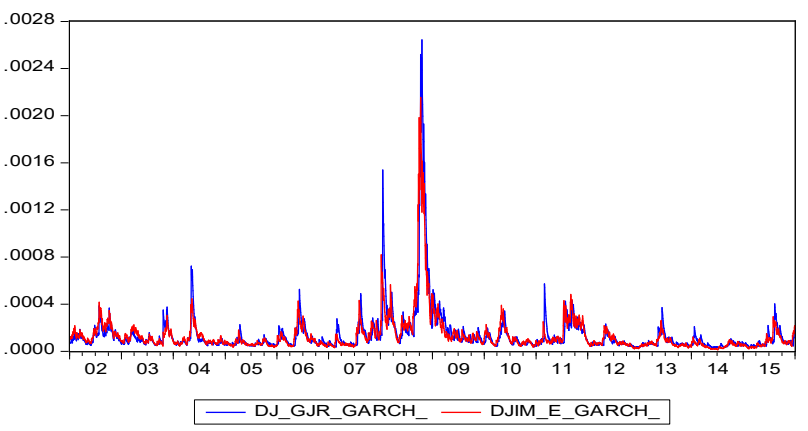

Europe Index

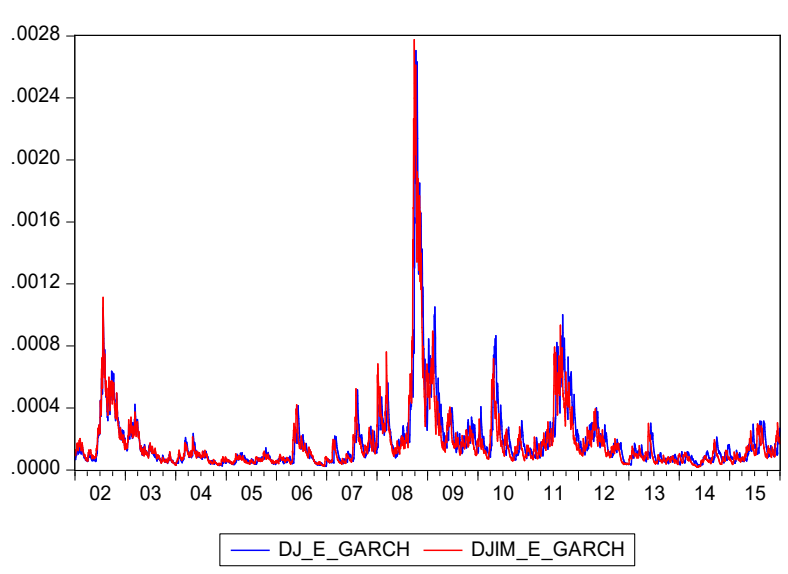

Emerging Markets Index

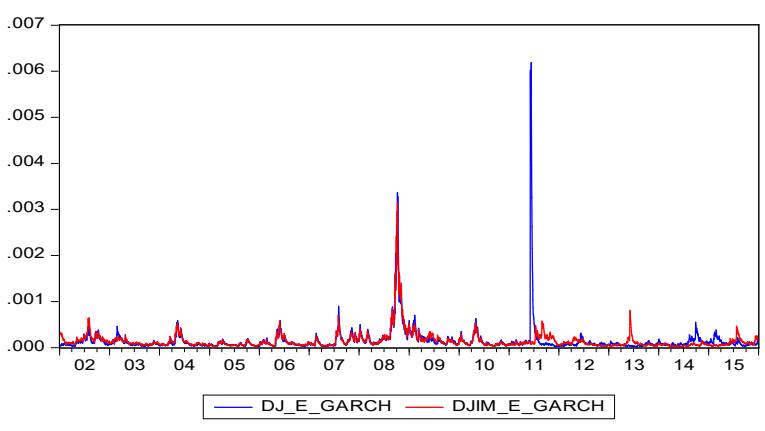

U.S. Index

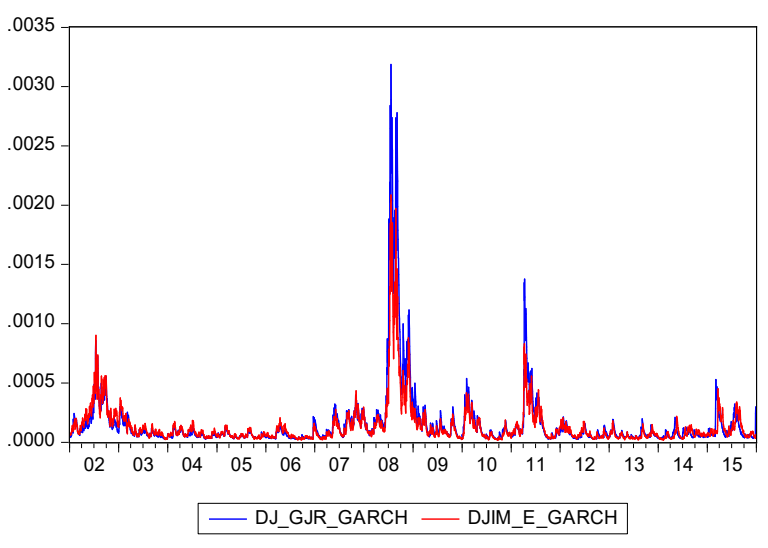


Global Index

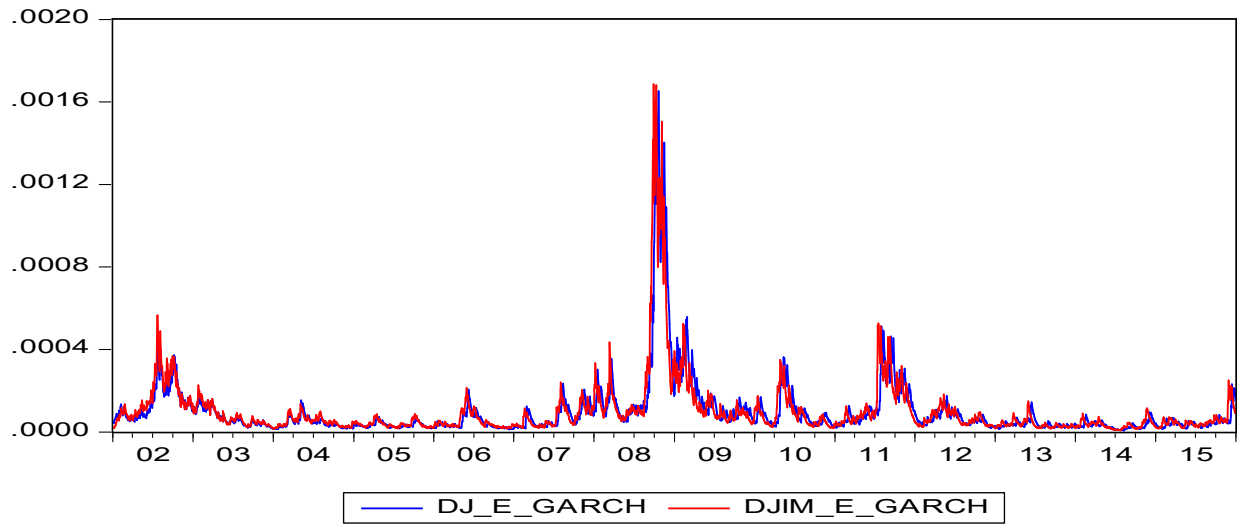

Figure 3. Volatility of stock indexes

\section{Copyright Disclaimer}

Copyright for this article is retained by the author(s), with first publication rights granted to the journal.

This is an open-access article distributed under the terms and conditions of the Creative Commons Attribution license (http://creativecommons.org/licenses/by/4.0/) 